\title{
Formation pathways of oriented magnetite micro-inclusions in plagioclase from oceanic gabbro
}

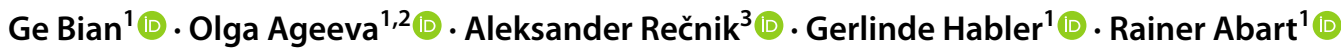

Received: 12 July 2021 / Accepted: 4 November 2021 / Published online: 22 November 2021

(c) The Author(s) 2021

\begin{abstract}
Plagioclase hosted needle- and lath-shaped magnetite micro-inclusions from oceanic gabbro dredged at the mid-Atlantic ridge at $13^{\circ} 01-02^{\prime} \mathrm{N}, 44^{\circ} 52^{\prime} \mathrm{W}$ were investigated to constrain their formation pathway. Their genesis is discussed in the light of petrography, mineral chemistry, and new data from transmission electron microscopy (TEM). The magnetite micro-inclusions show systematic crystallographic and shape orientation relationships with the plagioclase host. Direct TEM observation and selected area electron diffraction (SAED) confirm that the systematic orientation relations are due to the alignment of important oxygen layers between the magnetite micro-inclusions and the plagioclase host, a hypothesis made earlier based on electron backscatter diffraction data. Precipitation from Fe-bearing plagioclase, which became supersaturated with respect to magnetite due to interaction with a reducing fluid, is inferred to be the most likely formation pathway. This process probably occurred without the supply of Fe from an external source but required the out-diffusion of oxygen from the plagioclase to facilitate partial reduction of the ferric iron originally contained in the plagioclase. The magnetite micro-inclusions contain oriented lamellae of ilmenite, the abundance, shape and size of which indicate high-temperature exsolution from Ti-rich magnetite constraining the precipitation of the magnetite micro-inclusions to temperatures in excess of $\sim 600{ }^{\circ} \mathrm{C}$. This is above the Curie temperature of magnetite, and the magnetic signature of the magnetite-bearing plagioclase grains must, therefore, be considered as the thermoremanent magnetization.
\end{abstract}

Keywords Oriented plagioclase-hosted magnetite micro-inclusions - Correlated optical and electron microscopy · Crystallographic and shape orientation relationships $\cdot$ Exsolution

\section{Introduction}

Magnetite (MT) is the most important carrier of the natural remanent magnetization (NRM) of rocks. In igneous and metamorphic rocks, magnetite may be present as individual grains in the rock matrix, or, alternatively, it may

Communicated by Othmar Müntener.

Ge Bian

biang92@univie.ac.at

1 Department of Lithospheric Research, University of Vienna, Althanstrasse 14, 1090 Vienna, Austria

2 Institute of Geology of Ore Deposit, Petrography, Mineralogy, and Geochemistry, Russian Academy of Sciences (IGEM, RAS), Staromonetny 35, Moscow 119017, Russia

3 Department of Nanostructured Materials, Jožef Stefan Institute, Jamova cesta 39, 1000 Ljubljana, Slovenia occur in the form of $\mu \mathrm{m}$ to sub- $\mu \mathrm{m}$ sized usually oriented inclusions hosted by rock-forming silicate phases such as olivine, pyroxene, amphibole and feldspar (Fleet et al. 1980; Davis 1981; Dunlop and Özdemir 2001; Renne et al. 2002; Lappe et al. 2011; Usui et al. 2015; Knafelc et al. 2019). Oriented needle- and lath-shaped magnetite micro-inclusions are common in plagioclase (PL) and pyroxene (PX) from mafic intrusions and were described from the Skaergaard intrusion (Wager and Mitchell 1951), the Stillwater Igneous Complex (Montana, USA) (Selkin et al. 2014), the Jurassic Dufek (Cheadle and Gee 2017), Bushveld layered intrusion (Feinberg et al. 2006) and from oceanic gabbro (Kent et al. 1978; Davis 1981). Due to their peculiar magnetic properties, silicate-hosted magnetite micro-inclusions are of particular interest in paleomagnetic research (Chang et al. 2016; Biedermann et al. 2020). Their small size typically leads to single domain or pseudo-single domain magnetic behavior, which results in extraordinarily stable magnetization (Dunlop 1981; Feinberg et al. 2005; Tarduno et al. 2006, 2020). 
The crystallographic orientation relationships (CORs) and shape orientation relationships (SORs) between magnetite micro-inclusions and plagioclase host crystals have been rationalized earlier. Six frequently observed as well as two less common orientation classes of magnetite microinclusions in plagioclase host have been discerned (Sobolev 1990; Wenk et al. 2011; Ageeva et al. 2016, 2020). While the CORs and SORs between the magnetite micro-inclusions and the plagioclase host are well documented (Ageeva et al. 2020), the formation pathways of plagioclase-hosted magnetite micro-inclusions have not been fully revealed yet. Knowing the formation conditions of these inclusions is of pivotal importance for paleomagnetic reconstructions. In particular, the temperature at which they were formed decides on whether their magnetic memory is based on thermal or chemical remanence and whether they record the magnetic field during the high-temperature stage of the rocks or during an intermediate or low-temperature hydrothermal stage.

In this communication, we explore the origin of magnetite micro-inclusions in rock-forming plagioclase from an oceanic gabbro that was dredged at the mid-Atlantic ridge. We employed correlated optical microscopy including universal stage, scanning electron microscopy (SEM), electron probe microanalysis (EPMA), and transmission electron microscopy (TEM). In particular, high-resolution TEM imaging and selected area electron diffraction (SAED) were used to test the hypothesis on the CORs and the SORs between the magnetite micro-inclusions and the plagioclase host that have previously been put forward based on electron backscatter diffraction crystal orientation data (Ageeva et al. 2016, 2020). The combined evidence is used to construct a genetic model for the plagioclase-hosted magnetite microinclusions, and the implications for paleomagnetic reconstructions are discussed.

\section{Samples and geological background}

The material under study is taken from an oceanic gabbro dredged at the mid-Atlantic ridge. In this gabbro, the rockforming plagioclase shows abundant needle- or lath-shaped magnetite micro-inclusions. This feature is observed in all plagioclase grains of the gabbro and it is also common in plagioclase from gabbroic rocks from other sampling localities along the mid-Atlantic ridge at $11^{\circ} \mathrm{N}, 43^{\circ} \mathrm{W}$ to $17^{\circ} \mathrm{N}$, $45^{\circ} \mathrm{W}$ (Ageeva et al. 2016). Out of a series of gabbro specimen showing similar petrographic characteristics, specimen L30-277-7 from dredge line 30L 277 at the western flank of the rift valley at $13^{\circ} 01-02^{\prime} \mathrm{N}, 44^{\circ} 52^{\prime} \mathrm{W}$ in the course of the 30-th cruise of R/V "Professor Logachev" (2007) was selected as a representative sample. The gabbro pertains to a gabbro-peridotite association comprising peridotite-hosted gabbroic intrusions, which crop out in the footwall of a lowangle large-offset detachment fault, a structure that is typical for slow-spreading ridges (Smith et al. 2008; Silantyev et al. 2011; Ondréas et al. 2012; Peirce et al. 2019, 2020). The studied rock is a medium-grained gabbronorite consisting of plagioclase ( $60 \mathrm{vol} \%)$, ortho- and clinopyroxene $(\sim 30$ vol\%), amphibole $(\sim 10$ vol\%) and minor Fe, Ti oxides $(\leq 0.5$ vol $\%)$. The bulk rock compositions of gabbro specimen from the mid-Atlantic ridge at $13^{\circ} \mathrm{N}$ to $13.5^{\circ} \mathrm{N}$, $45^{\circ} \mathrm{W}$ are given in Table Sup- 1 of the supplementary material. The plagioclase has labradorite composition (mineral chemical analyses of plagioclase, orthopyroxene and clinopyroxene are presented in the supplementary material). It is hypidiomorphic and forms tabular and rarely subhedral 0.5-5-mm-sized grains. Based on its microstructural relations to pyroxene (see supplementary material, Fig. Sup1), plagioclase is inferred to have crystallized relatively early in the crystallization sequence, which is in line with the expected crystallization sequence of tholeiitic melt at the low pressures prevailing in a mid-ocean ridge environment (Grove and Baker 1984; Grove et al. 1992; Ariskin and Barmina 2004; Villiger et al. 2007; Suhr et al. 2008). The rocks analyzed by these latter authors compare well with the rocks under study, corroborating that plagioclase was the earliest phase to crystallize from the melt. Orthopyroxenes (En62-63Wo3-5, $\left.\mathrm{X}_{\mathrm{Mg}}=65-66\right)$ and clinopyroxenes (En39-42Wo41-48, $\mathrm{X}_{\mathrm{Mg}}=73-76$ ) occur as prismatic and subhedral grains $3-5 \mathrm{~mm}$ in size with a dense cleavage network and with clinopyroxene lamellae in orthopyroxene and vice versa. Clinopyroxene contains needle-shaped magnetite micro-inclusions and ilmenite plates ( $\leq 5 \mu \mathrm{m}$ thick). Rare magnesiohornblende $\left(\mathrm{X}_{\mathrm{Mg}}=74\right)$ locally replaces clinopyroxene. $\mathrm{Fe}-\mathrm{Ti}$ oxides are present as up to 1-mm-sized grains of magnetite, ilmenite, and exsolved titanomagnetite, that typically occupy interstitial positions in the rock matrix. Locally, pyroxene is replaced by actinolite indicating hydrothermal alteration at a relatively low temperature.

\section{Analytical methods}

\section{Optical microscopy}

A Leica DM4500 P optical microscope equipped with a Zeiss Axiocam 208 Colour camera was applied for polarization microscopy. The plagioclase-hosted magnetite micro-inclusions including their shape orientation relationships to the plagioclase host were observed under plane-polarized light. In cross-polarized light, plagioclase twinning and the respective twin boundaries could be identified and related to the distribution of the magnetite micro-inclusions. 


\section{Electron probe microanalysis}

A Cameca SXFiveFe electron probe micro-analyzer (FEG-EPMA), located at the Department of Lithospheric Research, University of Vienna (Austria), was used for mineral chemical analysis. The instrument is equipped with a FEG Schottky type field-emission gun electron source and with five crystal spectrometers for wavelength dispersive elemental analysis. The instrument was operated with an accelerating voltage of $20 \mathrm{kV}$ and a probe current of $8 \mathrm{nA}$. For routine point analyses of plagioclase, the beam was defocused to $5 \mu \mathrm{m}$ to minimize Na-loss. For the analysis of line profiles, a $20 \mu \mathrm{m}$ defocused beam was used to integrate over plagioclase and magnetite micro-inclusions. For quantitative analysis, the instrument was calibrated against well-characterized mineral standards, and the Phi-Rho- $\mathrm{Z}$ routine was employed for matrix correction.

\section{Scanning electron microscopy and focused ion beam application}

An FEI Quanta 3D FEG-SEM at the Faculty of Earth Sciences, Geography and Astronomy, University of Vienna (Austria) was used for secondary electron (SE) imaging and focused ion beam (FIB) preparation of specimens for investigation by TEM. The FIB-SEM is equipped with a Schottky type field-emission gun electron source, a liquid metal Gaion source gas injection system for Pt- and $\mathrm{C}$ deposition, and an Omniprobe 100.7 micromanipulator for in situ lift-out. SE imaging and TEM specimen extraction were applied to a chemo-mechanically polished carbon-coated thin section. SE images were collected at $15 \mathrm{kV}$ accelerating voltage and $4 \mathrm{nA}$ probe current. During imaging, the sample was at $14.5 \mathrm{~mm}$ working distance at the image center of the tilted sample. Applying the FIB technique, two site and orientation specific, about $50 \mathrm{~nm}$ thin $5 \mu \mathrm{m}$ by $10-\mu \mathrm{m}$-sized lamellae were extracted. The foils contain needle-shaped PL(112)n-MT and PL(150)n-MT micro-inclusions located near Albite twin boundaries of the plagioclase host, where PL $(h k l) n-M T$ denotes a magnetite micro-inclusion with its elongation direction parallel to the $\mathrm{PL}(h k l)$ plane normal. The FIB sections were oriented so that the elongation direction of the magnetite micro-inclusion is sub-parallel to the plane of the TEM foil, and the magnetite-plagioclase interfaces are perpendicular to the latter. During FIB preparation, the sputtering or deposition progress was monitored using electron beam (EB) induced SE imaging. The electron beam conditions were set to $10 \mathrm{kV}$ accelerating voltage and $0.13 \mathrm{nA}$ probe current, and FIB induced SE imaging was done at FIB settings of $30 \mathrm{kV}$ accelerating voltage and 10 $\mathrm{pA}$ to $1 \mathrm{nA}$ probe current. Platinum-deposition was applied to generate a protecting and supporting layer before specimen extraction, and to attach the TEM specimen first to the tungsten micromanipulator needle tip and finally to a $\mathrm{Cu}$ lift-out grid. During the Pt deposition steps, the FIB settings were at $30 \mathrm{kV}$ accelerating voltage and $0.1-0.3 \mathrm{nA}$, whereas during foil extraction the FIB probe current was successively lowered from 50 to $3 \mathrm{nA}$ or $1 \mathrm{nA}$. The about $2-\mu \mathrm{m}$-thick lamellae were transferred to the $\mathrm{Cu}$ grid by in situ lift-out. Subsequently, final thinning was performed at FIB settings of $30 \mathrm{kV}$ accelerating voltage and successively decreasing ion probe current of $1 \mathrm{nA}$ to $0.01 \mathrm{nA}$. Finally, a FIB cleaning step was applied to the surface planes of the finally thinned TEM specimen using a FIB accelerating voltage of $5 \mathrm{kV}$ and a FIB probe current of $48 \mathrm{pA}$. For both TEM specimen, the final foil thickness close to the Pt layer was at $50-60 \mathrm{~nm}$, whereas local parts of the foil adjacent to a perforation were thinner.

\section{Transmission electron microscopy and energy-dispersive X-ray spectroscopy}

A JOEL JEM-2100 TEM equipped with a $\mathrm{LaB}_{6}$ electron source operated under $200 \mathrm{kV}$ accelerating voltage was used for conventional TEM imaging and for selected area electron diffraction (SAED) experiments. High-resolution (HR) TEM imaging was done using a $200 \mathrm{kV}$ FEG JOEL-2010F TEM with a point resolution of $\sim 0.19 \mathrm{~nm}$, which allows for atomic structure observations. Both TEM instruments are located at the Jožef Stefan Institute, Department of Nanostructured Materials in Ljubljana, Slovenia. An analytical double-tilt sample holder with a tilt range of $\pm 15^{\circ}$ in both $\alpha$ and $\beta$ axes was used for precise alignments into specific zone axes. Since plagioclase has a rather complex crystal structure, the strategy for finding the desired zone axes was to refer to the zone axes of the embedded magnetite microinclusions. To obtain the proper CORs among individual phases, SAED patterns were recorded in two projections. SAED patterns from plagioclase were acquired with low excitation of condenser $\mathrm{C} 1$ lens separately from magnetite and the other phases due to the severe sensitivity to electron irradiation and consequent bending of the FIB foil. During HRTEM imaging, plagioclase became amorphous under high electron currents due to its extreme beam sensitivity. A $\mathrm{Si}(\mathrm{Li})$ energy-dispersive X-ray spectrometer (TEM-EDS) integrated within JOEL-2010F was used for elemental analysis. (HR)TEM images were processed and analyzed using DigitalMicrograph ${ }^{\mathrm{TM}}$ from Gatan Inc., USA.

\section{Results}

\section{Chemical composition of plagioclase}

The anorthite content of the plagioclase varies from An5851 in big, $\geq 4$-mm-sized grains to An53-50 in medium-sized 
grains to An52-48 in small, $\leq 0.5$-mm-sized grains. The lowest anorthite contents are An46, which are observed along healed cracks. Large, several mm-sized plagioclase grains are characterized by cloudy domains with grey stain in the grain interiors and by several hundred microns wide clear rims (Fig. 1a). The optical zoning is accompanied by chemical zoning with a continuous decrease of the anorthite content from An58 in the core to An51 in the rim. A profile of EPMA point analyses taken with a $20 \mu \mathrm{m}$ defocused beam and a step size of $15 \mu \mathrm{m}$ from the cloudy core into the clear rim is shown in Fig. 2. With the chosen analytical setting, each analysis averages over the plagioclase host and the abundant magnetite inclusions, and a nearly continuous coverage of the locally integrated compositions along the profile is obtained. It is seen that the total Fe content is more variable and generally higher in the cloudy core region, where it varies between 0.3 and $0.7 \mathrm{wt} \% \mathrm{FeO}_{\mathrm{T}}$, than in the clear rim, where $\mathrm{FeO}_{\mathrm{T}}$ is in the range of $0.25-0.3 \mathrm{wt} \%$. The comparatively high variability of the $\mathrm{FeO}_{\mathrm{T}}$ content in the core region is probably due to the effect of individual magnetite inclusions, which could not be eliminated completely through application of the defocused beam. On average, the $\mathrm{FeO}_{\mathrm{T}}$ in the cloudy core region is estimated to be about $0.45 \mathrm{wt} \%$, whereas it is only about $0.25 \mathrm{wt} \%$ in the clear
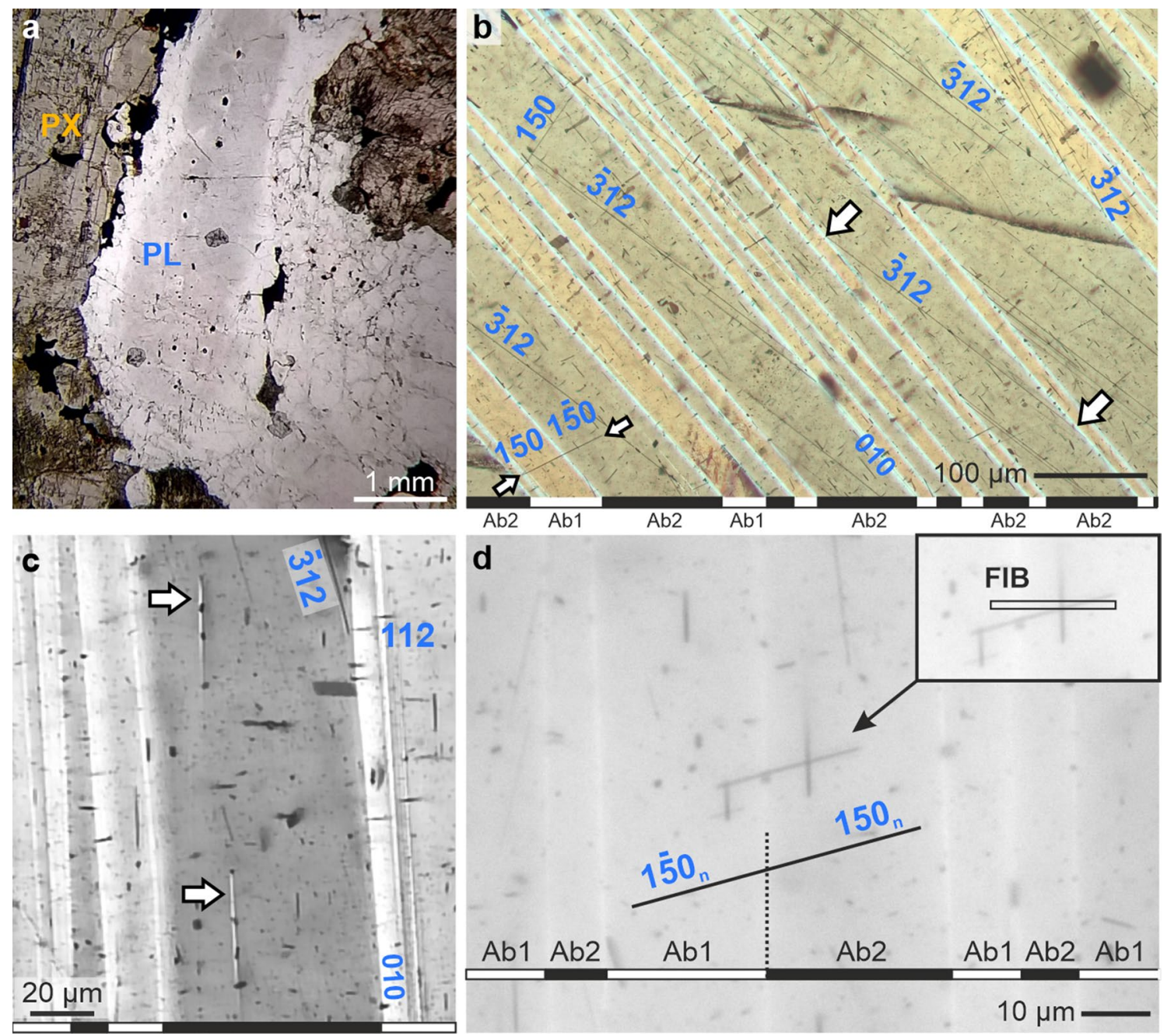

Fig. 1 Transmitted light images, a, d plane-polarized light, b, c crossed polarizers, of plagioclase. a Several mm-sized plagioclase grain with clouded core region and 100-200- $\mu$ m-wide clear rim. b Albite twinned plagioclase grain with magnetite micro-inclusions; arrows on the right show a PL( $\overline{3} 12) n-M T$ inclusion ending at Albite twin boundaries; arrows on the lower left show a PL(150)n-MT inclusion traversing an Albite twin boundary. c Domain of plagioclase with typical PL(112)n-MT inclusions, which appear short because they are oriented sub-perpendicular to the specimen surface, as well as $\mathrm{PL}(\overline{3} 12)$ n-MT which are sub-parallel to the specimen surface. The white arrows show small, lens-shaped Albite twin individuals with abundant isometric magnetite micro-inclusions. The magnetite needles that are oriented parallel to the twin boundaries are PL[001]-MT and PL(100)n-MT type needles (not labeled). d PL(150)n-MT inclusion traversing a twin boundary before extraction of a TEM foil (see Fig. 7). The trace of the TEM foil on the specimen surface is shown in the insert. The magnetite needle crossing the PL(150)n-MT inclusion shown in the insert is of PL[001]-MT type 


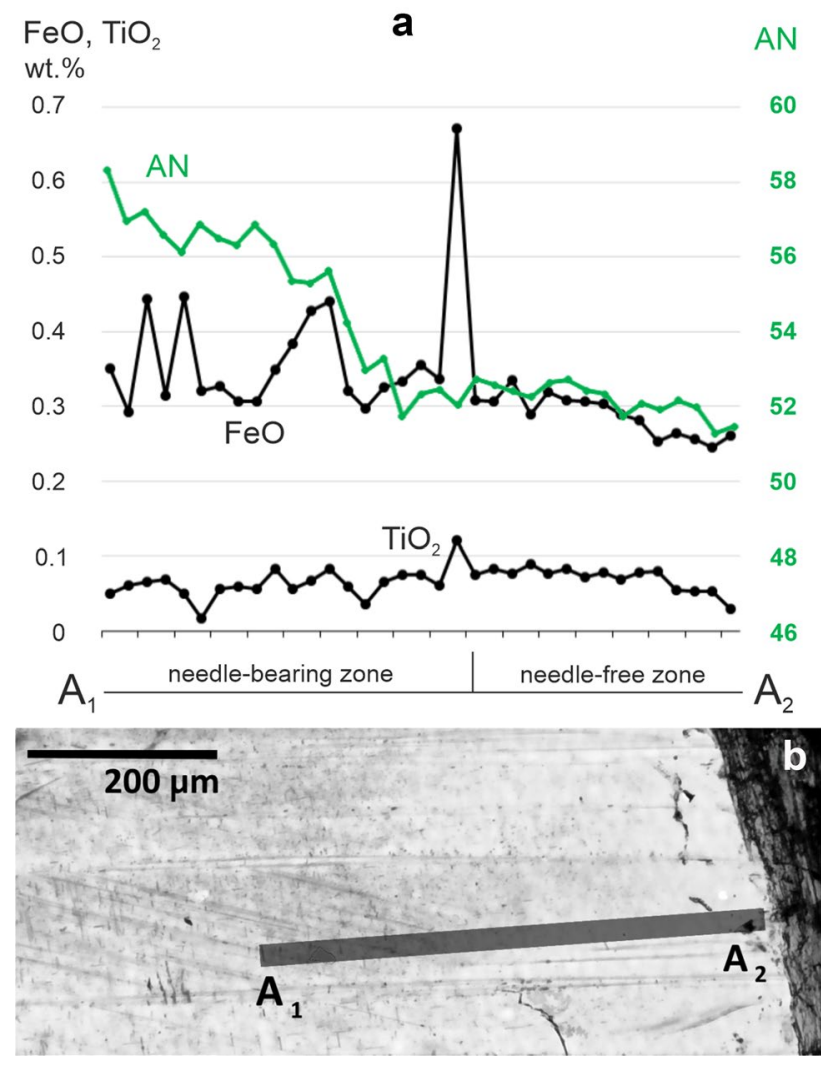

Fig. 2 Compositional variation along the core-to-rim profile $A_{1}-A_{2}$ traversing a needle-bearing and a needle-free zone of a plagioclase grain. a $\mathrm{FeO}_{\mathrm{T}}$ and $\mathrm{TiO}_{2}$ contents in wt $\%$ indicated by black and anorthite content (AN) by green lines. The spikes in the $\mathrm{FeO}_{\mathrm{T}}$ and $\mathrm{TiO}_{2}$ profiles are probably caused by magnetite inclusions. b Optical image (transmitted light) with profile line; the width of the line corresponds to the $20 \mu \mathrm{m}$ defocused beam used for microprobe analysis

rims. Measurements with a beam focused to $5 \mu \mathrm{m}$ produced more variable iron contents but the concentrations of $\mathrm{FeO}_{\mathrm{T}}$ were never below $\sim 0.25 \mathrm{wt} \%$. This value is also valid in the inclusion-free domains and is thus considered as the $\mathrm{FeO}_{\mathrm{T}}$ background concentration.

\section{Distribution and morphology of the micro-inclusions}

Under cross-polarized light, plagioclase twinning after the Manebach, Carlsbad, Albite and Pericline twin laws can be observed, where the latter two form polysynthetic twins (Fig. 1). If the cloudy domains in the grain interiors are viewed at high magnification under transmitted light, abundant lath- and needle-shaped $\mu \mathrm{m}$ and sub- $\mu \mathrm{m}$ sized magnetite grains appear. These magnetite micro-inclusions are present at up to $\sim 1 \mathrm{vol} \%$ and are responsible for the grey stain that is seen in the internal regions of the plagioclase grains. The clear rims are devoid of optically discernible magnetite micro-inclusions. The magnetite micro-inclusions show specific shape orientations, where four to five different shape orientation groups can usually be discerned in a given plagioclase domain (Fig. 1, also see the supplementary material, Figs. Sup-2, Sup-3). It has been shown by Ageeva et al. (2020) that the elongation directions of the so-called plane-normal type inclusions follow the normal directions of specific plagioclase lattice planes including the PL(112) n, PL(1 $\overline{5} 0) n, \operatorname{PL}(\overline{3} 12) n, \operatorname{PL}(150) n$ and PL(100)n directions, where $\mathrm{PL}(h \mathrm{kl}) \mathrm{n}$ designates the direction that is normal to the $\mathrm{PL}(h k l)$ plane. One additional inclusion type has its elongation direction parallel to the PL[001] direction. An overview image of a plagioclase domain showing magnetite microinclusions with five well discernible SORs with respect to the plagioclase host is shown in the supplementary material (Fig. Sup-2). The magnetite micro-inclusions investigated in detail in this study pertain to two of the plane-normal orientation classes, namely PL(112)n and PL(150)n.

The magnetite micro-inclusions are often bounded by plagioclase twin boundaries and change their shape orientations across twin boundaries. An overview image showing a plagioclase with magnetite micro-inclusions with shape orientations changing across Carlsbad and Albite twin boundaries is shown in the supplementary material (Fig. Sup-3). In Fig. 1b, a plagioclase grain with polysynthetic Albite twins labeled Ab1 and Ab2 is shown. PL( $\overline{3} 12) n-M T$ micro-inclusions are visible in the Ab2-oriented twin individuals. These micro-inclusions typically extend all across the Ab2-oriented twin individuals and are bounded by the twin boundaries on both sides. In the upper right of Fig. 1b, PL $(\overline{3} 12) n-M T$ micro-inclusions can be seen in both, Ab1 and $\mathrm{Ab} 2$ twin individuals, where they appear mirrored about the twin boundary. Out of the magnetite micro-inclusions of the different orientation classes, only those that are elongated parallel to PL(150)n or PL(1 $\overline{5} 0)$ n transverse the Albite twin boundaries, apparently without any change in the orientation of their elongation direction and shape. This is due to the invariance of these two directions with respect to the Albite twin operation. Another interesting feature is shown in Fig. 1c, where small, about $50 \mu \mathrm{m}$ long and 1-2 $\mu \mathrm{m}$ wide, lens-shaped Albite twin domains are accompanied by small, 1-2- $\mu \mathrm{m}$-sized magnetite micro-inclusions of isometric shape aligned along the twin individuals. In the studied material, the spatial association of the small magnetite micro-inclusions and twin boundaries is typical and suggests a relation between Albite twinning and the formation of the magnetite micro-inclusions.

\section{Magnetite-ilmenite intergrowth}

Several oriented sandwich-like lamellae of ilmenite (ILM) can be seen within the magnetite micro-inclusions (Figs. 3, 5a). The ilmenite lamellae are about $100-200 \mathrm{~nm}$ wide and mostly are oriented perpendicular to the elongation direction of the 

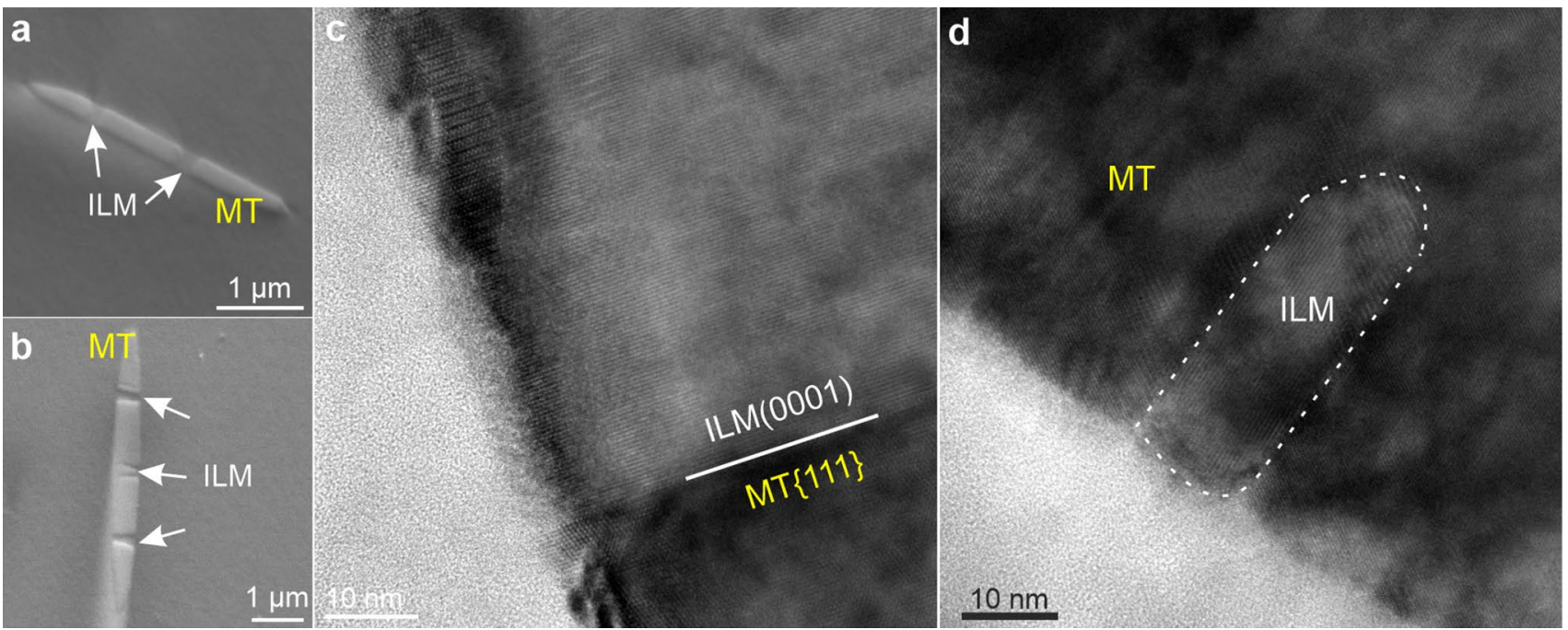

Fig. 3 a, b Tilt corrected secondary electron (SE) images obtained at $70^{\circ}$ tilt, showing magnetite micro-inclusions hosting sandwich-like ilmenite lamellae. c High-resolution TEM (HRTEM) image showing a sharp contact between an ilmenite lamella and the magnetite host.

hosting magnetite needle. The total amount of the ilmenite lamellae in magnetite is estimated to be less than $15 \mathrm{vol} \%$ of the opaque inclusion in all ilmenite-bearing inclusions. TEM observations show that the interface between ilmenite lamellae and magnetite host are sharp and that they are parallel to the $\operatorname{ILM}(0001)$ and one of the MT\{111\} lattice planes (Fig. 3c). In addition to the relatively coarse lamellae, tiny, several nmsized ilmenite domains are dispersed in the magnetite host (see highlighted domain in Fig. 3d).

\section{Composite micro-inclusions}

Sometimes the magnetite micro-inclusions are accompanied by orthopyroxene (OPX), clinopyroxene (CPX), amphibole, and mica so that composite multiphase inclusions arise. Orthopyroxene is the most abundant accompanying phase. Its volume fraction is in the range of $1-5 \%$ of the magnetite it accompanies. It can be seen in Fig. 5a that the smooth interface between magnetite and plagioclase is interrupted, where magnetite is in contact with orthopyroxene. In contrast, when present, amphibole and mica do not seem to interrupt the needle shape of the magnetite inclusion, they rather seem to have grown on top of the magnetite needle only replacing plagioclase (Fig. 5a).

\section{Crystallographic and shape orientation relationships between the magnetite micro-inclusions and the plagioclase host}

The CORs between the magnetite micro-inclusions and the plagioclase host were investigated using SAED and
The phase boundary is ILM(0001) ॥ MT\{111\}. d HRTEM image showing an ultra-fine ilmenite highlighted with white dashed line in a magnetite host

HRTEM. No direct image of both phases could be acquired at the same time, because of the extreme beam sensitivity of plagioclase. As the FIB foils are considerably bent, the SAED patterns at different positions within one crystal had to be acquired at slightly different tilting conditions to maintain a certain projection. (HR)TEM images and the corresponding SAED patterns of two PL(112)n-MT microinclusions and the plagioclase host are shown in Figs. 4 and 5. Originally, the two inclusions probably pertained to a single inclusion, which split into two separate inclusions in the course of recrystallization. The elongation directions are slightly different for the two related inclusions (Fig. 4a) indicating that the SORs and probably also the CORs were slightly modified during recrystallization and do not exactly represent the supposed original orientation relationships. The left inclusion in Fig. 4a is of polyphase nature while the right one is only comprised of a single magnetite needle. Small amounts of ilmenite are present at the tips of both segments of the split PL(112)n-MT micro-inclusion.

\section{Single-phase PL(112)n-MT micro-inclusion}

The elongation direction of the single-phase PL(112)n-MT micro-inclusion, that is the right inclusion in Fig. 4a, closely corresponds to $\vec{g}_{M T 111}$ (Fig. 4b), which is aligned parallel to $\vec{g}_{P L 112}$ (Fig. 4e), where $\vec{g}_{h k l}$ is the primitive lattice plane vector in reciprocal space, and the length of $\vec{g}_{h k l}$ is proportional to the reciprocal of the corresponding $d$-spacing in the direct lattice. The long magnetite-plagioclase interfaces defining the elongation direction of the inclusion are nearly perpendicular to the plane of the foil, so that they appear 
sharp under the chosen projection. The traces of these interfaces are sub-parallel to one of the MT\{110\} lattice planes, but in detail they are slightly curved and show an angular deviation of up to about $5^{\circ}$ from the trace of the MT $\{110\}$ plane. The nearly identical values of $\vec{g}_{M T 222}$ and $\vec{g}_{P L 112}$, with respect to both, orientation and length (Fig. 4d, e), imply that the MT\{222\} and the PL(112) lattice planes are well aligned across the magnetite-plagioclase interface, with only minute lattice mismatch. Defining the relative lattice misfit as $\left|d_{P L 112}-d_{M T 222}\right| / d_{M T 222}$ a numerical value of 0.014 is obtained using 1 bar $298 \mathrm{~K}$ crystallographic data from Wenk et al. (1980) for plagioclase and from O'Neill and Dollase (1994) for magnetite. The MT\{222\} lattice planes are clearly visible on the HRTEM image of the magnetite-plagioclase interface (Fig. 4c). No fringes of the corresponding PL(112) lattice plane can, however, be observed because of the extremely quick amorphization of the plagioclase under the electron beam.

\section{Composite PL(112)n-MT micro-inclusion}

A bright-field TEM image and SAED patterns of the part of the split PL(112)n-MT needle that forms the composite inclusion, that is the left inclusion in Fig. $4 \mathrm{a}$, are shown in Fig. 5. The inclusion comprises magnetite, ilmenite, orthopyroxene and mica. The crystallographic orientation relationships of the two parts of the split PL(112)n-MT needle to the plagioclase host and with respect to the accompanying phases are shown in Fig. 6. According to its elongation direction and the COR to the plagioclase host, the magnetite inclusion is still classified as a PL(112)n-MT micro-inclusion, albeit with an about $10^{\circ}$ deviation from the elongation of the single-phase PL(112)n-MT micro-inclusion. The magnetite contains irregularly distributed lamellae of ilmenite, which show a SOR parallel to the MT\{111\} lattice plane that is perpendicular to the needle elongation direction. The ilmenite shows a specific COR with the magnetite with MT\{111\} || ILM(0001) and MT\{110\} || ILM(1010), which also implies MT $<112>\|$ ILM[12 10$]$. This crystallographic orientation relationship has been reported from several cases of magnetite-ilmenite intergrowth in the literature (Feinberg et al. 2005; Wenk et al. 2011) and is ascribed to the parallel alignment of close-packed oxygen layers parallel to $\operatorname{MT}\{111\}$ in the cubic close-packed (ccp) oxygen sublattice of magnetite and parallel to ILM(0001) in the hexagonal close-packed (hcp) oxygen sublattice of ilmenite. In addition, the observed COR ensures parallel alignment of closepacked directions within these layers.

Orthopyroxene and mica are locally present along the long interfaces bounding the magnetite needle parallel to its elongation direction. In the domain shown in Figs. 4a and $5 \mathrm{a}$, the orthopyroxene forms an elongated grain parallel to the elongation direction of the magnetite needle. The
SAED patterns in Fig. 5 reveal a specific COR between magnetite and orthopyroxene with MT $\{111\} \|$ OPX(100) and MT $\{110\} \| \operatorname{OPX}(010)$, which also implies MT $<112>\|$ OPX [001]. The COR between magnetite and orthopyroxene is very precise indicating a direct contact between magnetite and orthopyroxene during growth of orthopyroxene on pre-existing magnetite or, vice versa, growth of magnetite in contact with pre-existing orthopyroxene. The orthopyroxene has a relatively smooth interface towards the plagioclase but a wavy, somewhat irregularly shaped interface to the magnetite. The shapes of magnetite and orthopyroxene, and especially the geometry of the magnetite-orthopyroxene interface suggest that a pre-existing magnetite was partially replaced by orthopyroxene. Similar inferences were made by Gao et al. (2018), who observed scalloped magnetite-amphibole interfaces, where magnetite was partially replaced by amphibole.

Based on chemical composition and SAED patterns, the phase on the other side of the magnetite inclusion in Fig. 5a is most likely biotite (BT). The SAED patterns in Fig. 5 reveal a specific COR between magnetite and biotite with $\operatorname{MT}\{111\} \|$ BT(100) and MT\{110\} II BT(010), which also implies $\mathrm{MT}<112>\| \mathrm{BT}[001]$. In contrast to the interface segment where magnetite is in contact with orthopyroxene, the segment of the magnetite perimeter that is in contact with mica appears to have remained unaffected by the mica.

In summary, specific CORs with MT\{111\} ॥ ILM(0001) \| OPX(100) || BT(100) and MT\{110\} || ILM(1010) \| OPX(010) || BT(010), which also imply MT < 112> | ILM $[\overline{1}$ 210] || OPX[001] || BT[001], exist among all phases of the composite inclusion. In addition, the COR of the magnetite from the composite inclusion deviates by about $10^{\circ}$ from the COR of a single-phase PL(112)n-MT micro-inclusion with the plagioclase host. The $d$-spacings of the PL(112), $\operatorname{MT}\{111\}$ and OPX(100) lattice planes are related by close to integer multiples with $4 \times d_{M T 111}=4 \times 4.85 \AA \approx d_{O P X 100}$ $=18.36 \AA \approx 8 \times d_{P L 112}=8 \times 2.46 \AA$, so that a fair lattice match is ensured across magnetite-orthopyroxene $(0.053 \mathrm{rel}$. misfit), magnetite-plagioclase (0.014 rel. misfit), orthopyroxene-plagioclase ( 0.066 rel. misfit) interfaces extending approximately parallel to the needle elongation direction.

\section{PL(150)n-MT micro-inclusion}

Figure 7a shows a low-magnification TEM image of a PL(150)n-MT micro-inclusion. The elongation direction of the magnetite needle is sub-parallel to one of the $\mathrm{MT}<111>$ directions. In addition, the needle elongation direction and thus also the corresponding MT $<111>$ direction closely coincide with the normal direction to the PL(150) lattice plane of the plagioclase host. The magnetite-plagioclase interfaces bounding the inclusion parallel to its elongation direction on both sides closely correspond to a 


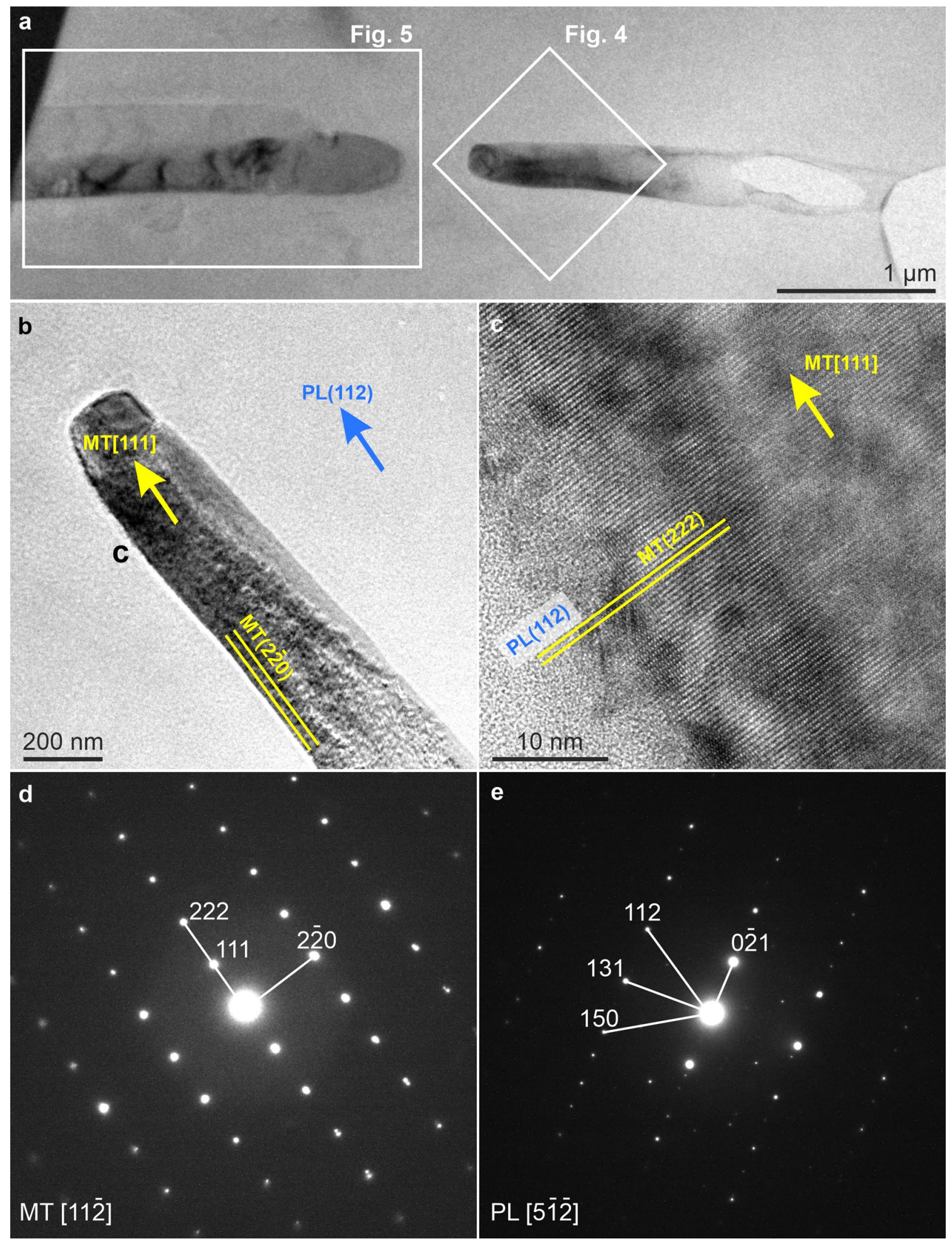


4Fig. 4 a Low-magnification bright-field TEM image of a split PL(112)n-MT micro-inclusion and surrounding plagioclase. b-e Refer to the right part of the split needle shown in a. b, c HRTEM image of the MT (upper right) plagioclase (lower left) interface; yellow arrow indicates the inclusion elongation direction; yellow line duplets show the traces of the MT(222) and MT(2-20) lattice planes. The lattice fringes of MT(222) are clearly visible, the associated MT[111] corresponds to the inclusion elongation direction. The plagioclase has been amorphized due to beam damage. d SAED pattern of magnetite viewing direction MT[112] . e SAED pattern of plagioclase viewing direction PL[5 $\overline{12}]$. From comparing $\mathbf{d}$ and $\mathbf{e}$, it becomes obvious that the length and orientations of $\vec{g}_{M T 222}$ and $\vec{g}_{P L 112}$ are nearly identical

MT $\{110\}$ facet (Fig. 7c, d). In Fig. 7c, this interface appears to be sharp, while in Fig. 7d, it has a somewhat wavy appearance on the nm-scale. The lattice fringes of the corresponding lattice planes in the plagioclase host cannot be seen due to the rapid amorphization of the plagioclase under the electron beam. As a consequence, the exact degree of alignment of the magnetite-plagioclase interfaces with the lattice planes of the plagioclase host cannot be directly observed. The SAED patterns shown in Fig. 7e, f reveal that $\vec{g}_{M T 222}$ is nearly identical to $\vec{g}_{P L 150}$, implying that the MT $\{222\}$ planes that are oriented perpendicular to the needle elongation direction are very well aligned with the PL(150) lattice planes with only a minute relative misfit of $\mid d_{P L 150}-d_{M T 222}$ $1 / d_{M T 222}=0.012$ across the magnetite-plagioclase interface bounding the inclusion parallel to its elongation direction. When the inclusion passes through an Albite twin boundary, the PL(150)n-Mt inclusion becomes a PL(150)n-Mt inclusion. This transformation will be further addressed in the "Discussion".

\section{Discussion}

The foremost interest in this study is to unravel the potential formation pathway(s) of the plagioclase-hosted magnetite micro-inclusions and to constrain their formation temperatures. This is of crucial importance for the interpretation of the remanent magnetization of the magnetite-bearing plagioclase grains.

One may consider that magnetite and the potentially accompanying phases crystallized from the melt first. The observed shape orientation relationships (SORs) and crystallographic orientation relationships (CORs) could then be generated in the course of attachment of the magnetite and accompanying phases to the surface of the growing plagioclase according to the best geometrical fit of their macroscopic shape, a process referred to as synneusis (Vance 1969). For the case at hand, this hypothesis can be rejected, because given a MORB type chemistry of the bulk rock, plagioclase crystallizes before orthopyroxene and magnetite at the conditions expected for crystallization in a mid-ocean ridge environment (Grove and Baker 1984; Grove et al. 1992; Ariskin and Barmina 2004; Villiger et al. 2007; Suhr et al. 2008).

Based on the combined petrographic, mineral chemical and microstructural evidence, we discuss two hypotheses for their genesis:

Hypothesis 1: Nucleation and growth of magnetite and potentially associated phases on the surface of plagioclase growing from the melt and engulfment during further plagioclase growth.

Hypothesis 2: Precipitation of magnetite and potentially associated phases from Fe-bearing plagioclase in a solid-state reaction or in a sequence of solid-state reactions.

The first hypothesis implies that magnetite and the potentially accompanying phases nucleated on the surface of the growing plagioclase. The newly forming magnetite and potentially accompanying phases thus would grow in contact with the plagioclase, at least along parts of their surfaces, allowing for the evolution of systematic CORs by topotaxy (Griffiths et al. 2021).

The second hypothesis implies that the magnetite and the accompanying phases precipitated from an Fe-bearing plagioclase, which became supersaturated with respect to magnetite (Wenk et al. 2011; Biedermann et al. 2016; Nikolaisen et al. 2020). In this case, the magnetite and the accompanying phases were in contact with the crystal structure of the host plagioclase during their entire nucleation and growth history. Thus, systematic SORs and CORs are expected to form so that the elastic strain energy due to macroscopic misfit and the interfacial energy arising from lattice mismatch at the newly generated phase boundaries are minimized.

With respect to the chemical mass balance, the first hypothesis implies that the $\mathrm{Mg}, \mathrm{Fe}^{2+}$ and $\mathrm{Fe}^{3+}$ needed for the formation of magnetite and associated phases were never present in the crystal structure of plagioclase. In contrast, according to the second hypothesis, the $\mathrm{Mg}, \mathrm{Fe}^{2+}$ and $\mathrm{Fe}^{3+}$ needed for the formation of magnetite and associated phases were derived from or delivered through the plagioclase, and local chemical mass balance needs to be taken into consideration. Two end-member scenarios are conceivable for precipitation of magnetite from supersaturated plagioclase. The plagioclase host crystal may have behaved as a closed system. This would require that the $\mathrm{Mg}, \mathrm{Fe}^{2+}$ and $\mathrm{Fe}^{3+}$ needed were originally present in the lattice of plagioclase. In this case, supersaturation with respect to magnetite could only arise from changes in temperature and/or pressure, where cooling is the most likely scenario. Alternatively, the plagioclase crystal may have been open with respect to chemical mass transfer allowing for the exchange of chemical components between 

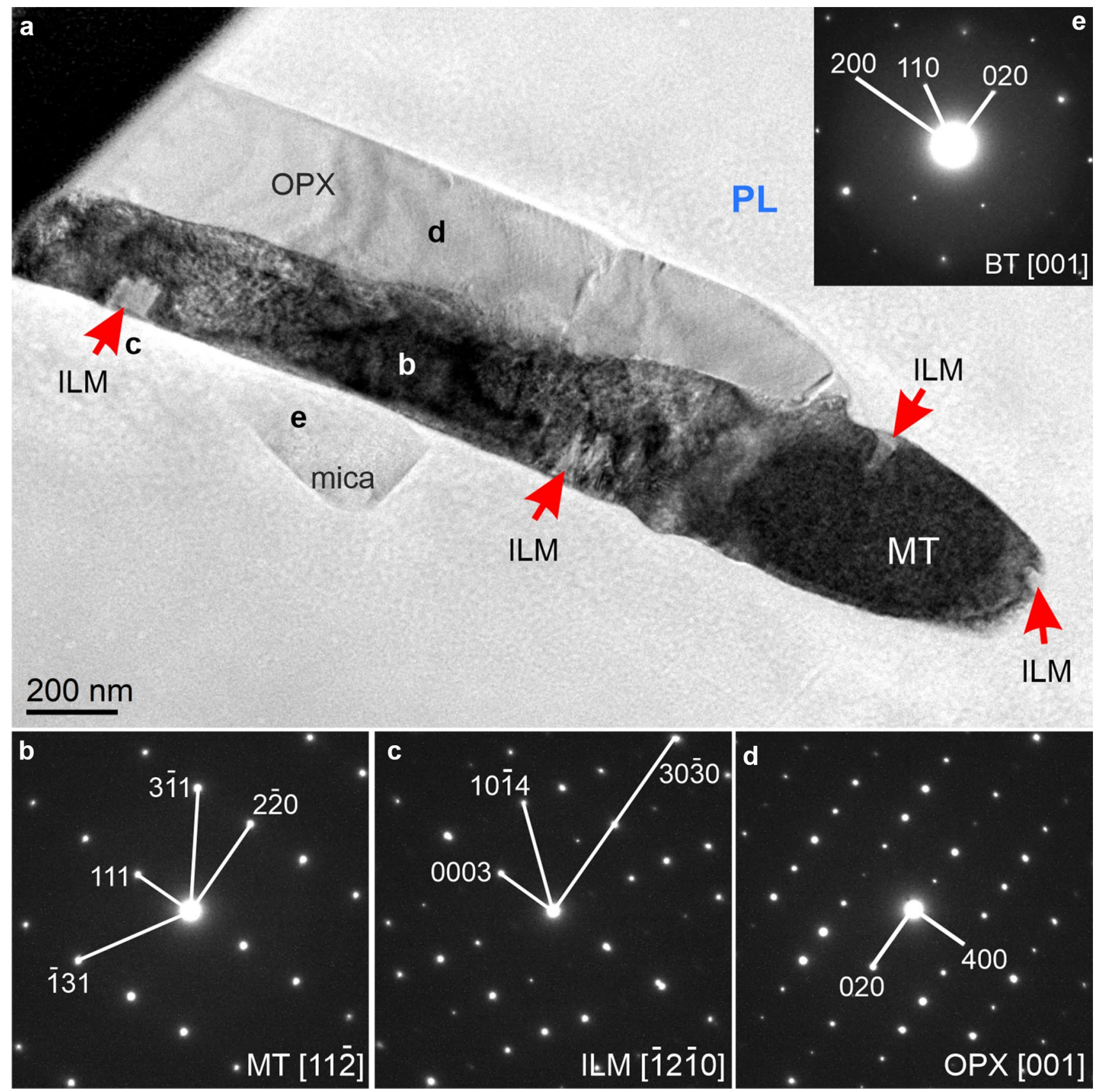

Fig. 5 a Bright-field TEM image of the left part of the split PL(112) n-MT needle shown in Fig. 4a; this is a composite micro-inclusion comprising PL(112)n-MT with ilmenite lamellae and accompanying orthopyroxene and mica locally growing between the plagioclase host and the magnetite. b-e SAED patterns of magnetite, ilmenite, orthopyroxene and mica; the locations where SAED patterns were taken are indicated by lower case alphabetical labels in a. Systematic CORs exist among all four inclusion phases, namely $\operatorname{MT}\{111\}$ \| $\operatorname{ILM}(0001)$ || OPX(100) ॥ $\mathrm{BT}(100), \operatorname{MT}\{110\}$ || ILM(1010) \| $\mathrm{OPX}(010) \| \mathrm{BT}(010)$, and as a consequence, $\mathrm{MT}<112>\| \mathrm{ILM}[\overline{1} 2 \overline{1} 0]$ || OPX[001] || BT[001]

magnetite would then be referred to as open system precipitation (Proyer et al. 2013). In the following, we discuss the possible formation pathways in the light of the observed crystallographic and shape orientation relationships, microstructural and chemical evidence. 


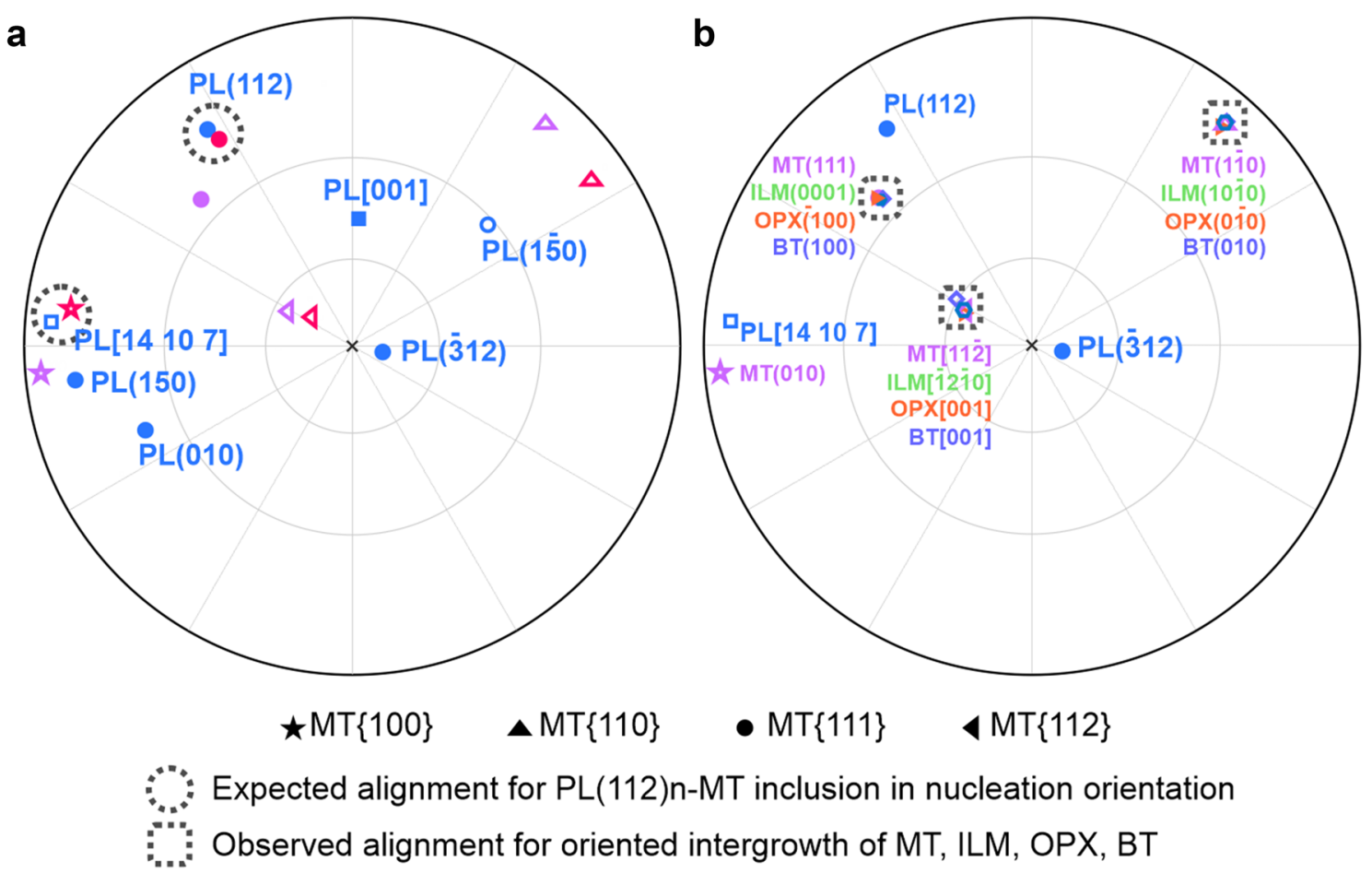

Fig. 6 a Stereographic projections showing the crystallographic orientations of the single-phase PL(112)n-MT magnetite inclusion (red) and of the composite micro-inclusion with magnetite (purple) to the plagioclase host (blue). The plane poles and directions that are expected to coincide for a PL(112)n-MT magnetite inclusion (Ageeva et al. 2020) are indicated with the dashed circles. b CORs of the phases pertaining to the composite micro-inclusion. The coincidence

\section{Implication of the observed crystallographic and shape orientation relationships}

\section{Single-phase PL(112)n-MT micro-inclusion}

According to the classification scheme of Ageeva et al. (2020), the main orientation of the PL(112)n-MT inclusions is defined as MT\{111\} \| PL(112) and MT\{110\} \| PL(150). In the case at hand, MT $\{111\} \| \operatorname{PL}(112)$ is fulfilled within the accuracy of the orientation determination, but the lattice of the magnetite inclusion is rotated away from the main orientation by about $29^{\circ}$ around its elongation direction. This rotation preserves the alignment of oxygen layers that are parallel to one of the MT\{111\} and to the PL(112) lattice planes. It may be a primary feature, or it may be due to recrystallization. According to Ageeva et al. (2020), the nucleation orientation of the PL(112)n-MT inclusions is defined as MT $<001>\| \operatorname{PL}\left[\begin{array}{ll}14 & 10\end{array}\right]$ and $\operatorname{MT}\{111\}$ II PL(112), which is rather close to the observed COR (Figs. 4b-e, 6a). Accordingly, the single-phase PL(112) n-MT inclusion is classified as "near nucleation orientation".

The coincidence of the $\vec{g}_{M T 222}$ and $\vec{g}_{P L 112}$ in reciprocal space reveals that these two lattice planes are well aligned of the plane poles and directions among the different phases (Fig. 5) are indicated with the dashed squares. The orientation of the PL(112) n-MT single-phase inclusion (red) coincides almost perfectly with the expected nucleation COR, while the orientation of the composite PL(112)n-MT micro-inclusion (purple) deviates by about $10^{\circ}$ from the ideal COR

with only a minute mismatch of about 0.014 between the corresponding $d$-spacings across the magnetite-plagioclase interfaces bounding the magnetite needle parallel to its elongation direction. The SAED data thus corroborate the supposition expressed earlier by Ageeva et al. (2020) that the alignment of important oxygen layers from both crystal structures is the mechanism underlying the systematic SOR and COR between the magnetite micro-inclusions and the plagioclase host and also explain the high aspect ratios of the magnetite micro-inclusions.

\section{Composite PL(112)n-MT micro-inclusion}

The part of the split PL(112)n-MT needle that forms the composite inclusion (Figs. 5, 6) is characterized by excellent alignment of MT\{111\} with OPX(100) and $\operatorname{ILM}(0001)$ but an about $10^{\circ}$ misorientation of these lattice planes with respect to $\operatorname{PL}(112)$. Like MT\{111\}, the $\operatorname{OPX}(100)$ and the ILM(0001) lattice plane correspond to close-packed oxygen layers. The $d$-spacings of these lattice planes are related by nearly integer factors, so that a good match across the magnetite-orthopyroxene and the magnetite-ilmenite phase boundaries is ensured. 

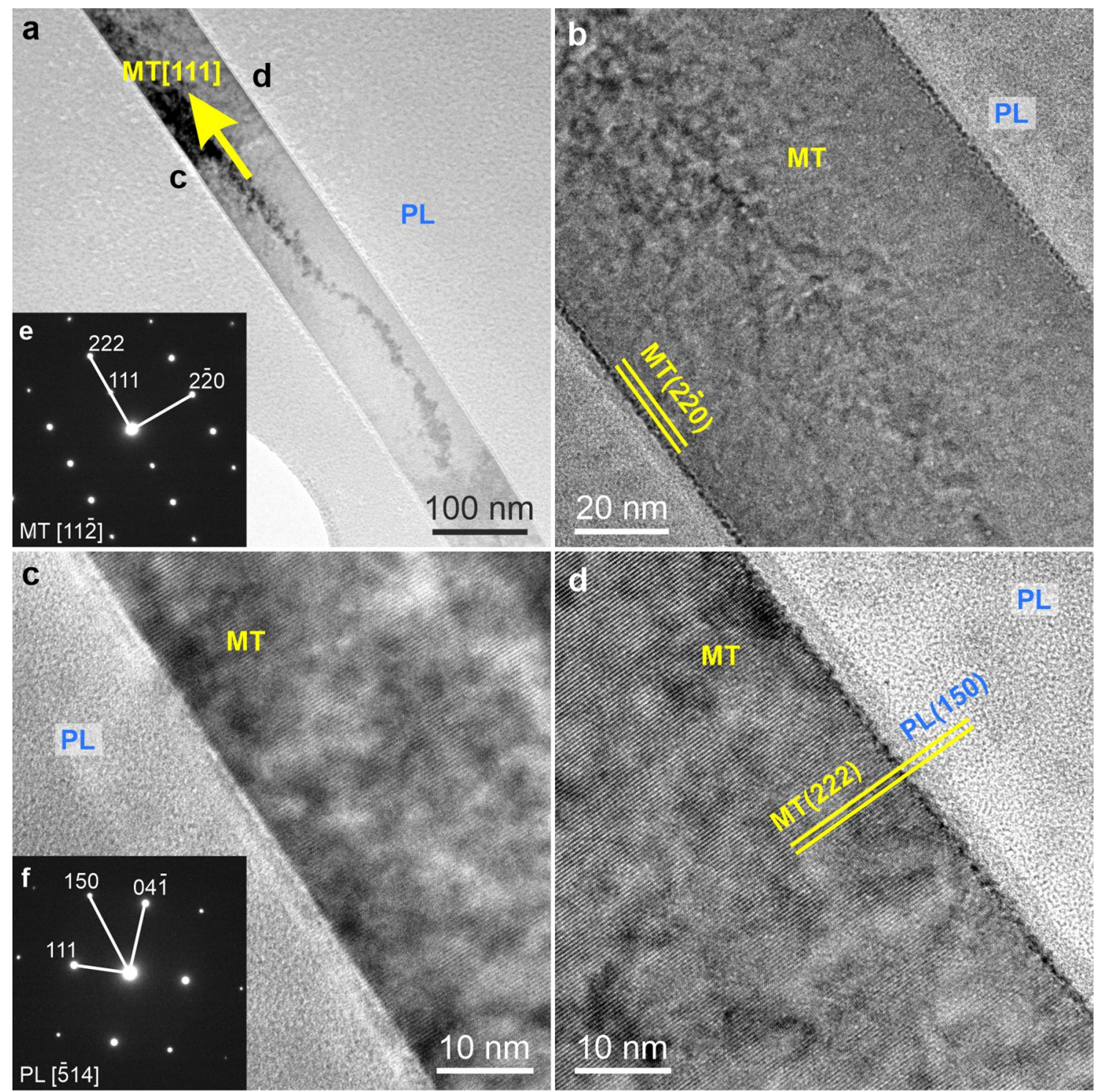

Fig. 7 a Bright-field TEM images of a PL(150)n-MT inclusion under low-magnification. b HRTEM image showing the magnetite-plagioclase interface on both sides of the magnetite micro-inclusion. c HRTEM image showing the sharp boundary from the lower part of $\mathbf{b}$.

The orientation of the single-phase PL(112)n-MT microinclusion corresponds to the expected COR more closely than the orientation of the magnetite from the composite inclusion (Fig. 6). This suggests that the deviation from the expected COR for a PL(112)n-MT micro-inclusion may arise from strain associated with the growth of orthopyroxene and the other accompanying phases. In any case, the strong CORs among magnetite, orthopyroxene and ilmenite indicate that orthopyroxene and ilmenite grew together with or on the pre-existing magnetite. d HRTEM image showing the wavier boundary from the upper part of b. e, f SAED patterns of magnetite under the MT[11 $\overline{2}]$ zone axis and plagioclase under zone axis PL[514]. Comparing $\mathbf{e}$ and $\mathbf{f}, \vec{g}_{M T 222}$ is nearly identical to $\vec{g}_{P L 150}$ with regard to length and orientation

\section{PL(150)n-MT micro-inclusion}

According to Ageeva et al. (2020), the main orientation of $\operatorname{PL}(1 \overline{5} 0)$ n-MT inclusions is defined as MT $\{111\} \| \operatorname{PL}(1 \overline{5} 0)$ and MT $\{110\} \| \operatorname{PL}(112)$. The SAED of the investigated PL(150)n-MT inclusion reveals that MT $\{111\} \| \operatorname{PL}(150)$ and MT $\{112\} \| \operatorname{PL}(\overline{3} 12)$ (Fig. 7). This COR can be explained as an effect of plagioclase twinning after the Albite law. The PL $(1 \overline{5} 0)$ and PL(150) lattice planes are perfectly parallel in two plagioclase domains that are related by the Albite twin 
law. As a consequence, the plane-normal directions have identical orientation and a PL(150)n-Mt inclusion becomes a PL(150)n-Mt inclusion, when it passes through an Albite twin boundary (Figs. 1d, 8). At the same time, the second alignment of lattice planes that defines the specific COR between magnetite micro-inclusion and plagioclase host changes from $\operatorname{MT}\{110\} \| \operatorname{PL}(112)$ to $\operatorname{MT}\{112\} \| \operatorname{PL}(\overline{3} 12)$ (Fig. 8). Thus, when passing through an Albite twin boundary, the $\operatorname{PL}(1 \overline{5} 0) n-M T$ inclusions preserve their elongation direction, but the descriptions of the COR are different in the two twin domains of the plagioclase host. Again, the coincidence of the $\vec{g}_{M T 222}$ and $\vec{g}_{P L 150}$ in reciprocal space indicates a good match between these two lattice planes across the magnetite-plagioclase interface of PL(150)n-MT inclusions, and further corroborates that the elongation direction of the plane-normal type inclusions is determined by the alignment of important oxygen layers from both crystal structures.

Despite of the angular deviation of the composite inclusion from ideal topotaxy, which is ascribed to recrystallization, all three inclusions investigated in this study correlate with the plane-normal orientation classes that were identified earlier from large electron backscatter diffraction data sets (Ageeva et al. 2020). The HRTEM imaging and the SAED results confirm the alignment of the lattice planes corresponding to close-packed oxygen lattice planes of magnetite with important oxygen layers of the host plagioclase.
These results suggest oriented nucleation and growth of magnetite in contact with a pre-existing plagioclase lattice. The fact that the SORs and CORs are fixed to the lattice of plagioclase in the different twin individuals indicates that the twinning, including Albite twinning, already existed, when the magnetite inclusions formed or at least when they attained their final orientation relationships to the plagioclase host. The fact that the orthopyroxene and mica grains accompanying the magnetite in the composite inclusion strictly adhere to specific CORs indicates that they grew either together with or after the formation of magnetite.

The observed SORs and CORs are still compatible with oriented nucleation of magnetite and potentially accompanying phases on the surface of growing plagioclase (hypothesis 1) as well as with the precipitation from supersaturated plagioclase (hypothesis 2 ). It has been shown recently that specific SORs tend to be selected depending on the orientation of the growth facet, if needle-shaped micro-inclusions are formed by oriented nucleation on the surface of a growing crystal (Griffiths et al. 2021). In the plagioclase under consideration, the SORs of the magnetite micro-inclusions always follow specific crystallographic directions, and differences in SOR between different domains in a plagioclase grain are only due to the effect of twinning. There is no evidence for selection of subsets of SORs in different domains that could have arisen from the effect of oriented

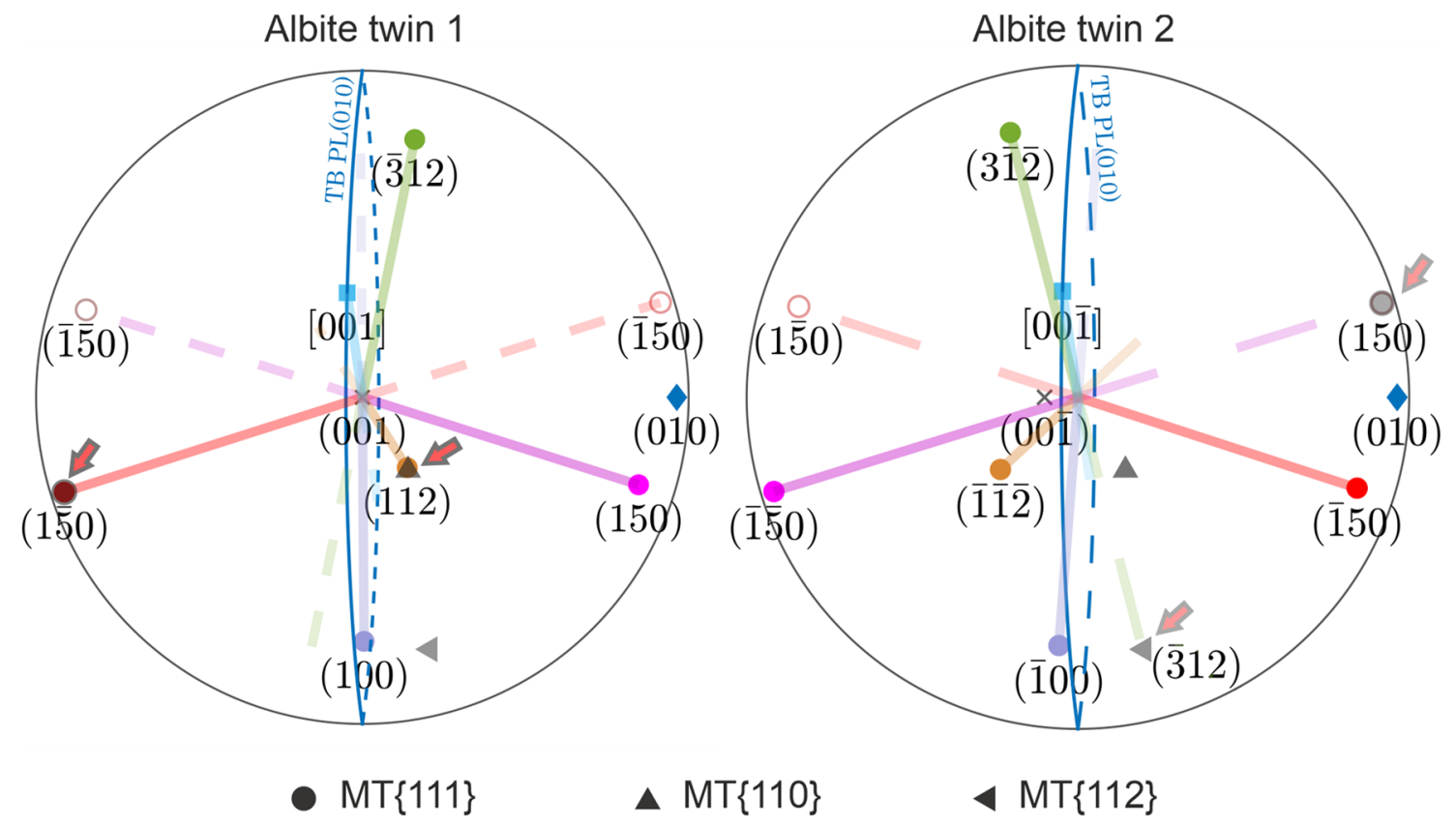

Fig. 8 Stereographic projections showing the elongation directions of the magnetite inclusions in the plagioclase host and their relations to the Albite twin law. All elongation directions change orientation when subjected to the Albite twin operation, except for the $\operatorname{PL}(1 \overline{5} 0)$ $\mathrm{n}$ and the PL(150)n type inclusions. A PL(150)n-MT inclusion in an Albite twin 1 has exactly the same orientation of its elongation direc- tion as a PL(150)n-MT type inclusion in Albite twin 2. The blue large circle labeled (010) represents the Albite twin boundary. The black symbols indicate lattice plane poles of the magnetite inclusion. The magnetite lattice planes that are aligned parallel to important oxygen layers in plagioclase for PL(150)n and the PL(150)n needles in the two different Albite twins are highlighted with the orange arrows 
nucleation on different growth facets. This is why hypothesis 1 is rejected, and precipitation of magnetite and possibly of magnetite and accompanying pyroxene from a supersaturated plagioclase host is considered as the most likely formation pathway. In addition to the microstructural and textural analyses, mass balance considerations may provide important constraints on the formation pathways of the magnetite inclusions in the plagioclase host. Possible mass balance scenarios are discussed in the following section.

\section{Mass balance considerations for precipitation from the plagioclase host}

If the magnetite inclusions formed by precipitation from a supersaturated $\mathrm{Fe}$-bearing plagioclase, the question arises, whether this is stoichiometrically possible in a closed system setting, or whether open system precipitation needs to be invoked. The former case would imply that all components needed for the formation of magnetite were derived from the plagioclase host crystal exclusively, while in the latter case, chemical mass transfer through the plagioclase host would need to be allowed, and any chemical change within the plagioclase host could be achieved by exchange with the surrounding melt or rock matrix.

From petrographic evidence, the volume fraction of the magnetite inclusions in the investigated plagioclase crystals is estimated to be $\leq 1 \%$. Together with the measured background concentration of about $0.25 \mathrm{wt} \% \mathrm{FeO}_{\mathrm{T}}$ in inclusionfree domains of plagioclase, this amounts to an overall $\mathrm{Fe}$ content of about $0.6 \mathrm{wt} \%$ in the plagioclase host. This is well within the range of typical Fe contents of plagioclase from gabbroic rocks, where plagioclase usually has $\mathrm{FeO}_{\mathrm{T}}$ contents of 0.2-1.0 wt\% (Smith and Brown 1988; Bernstein et al. 1992; Tegner 1997; Brandriss and Bird 1999).

The sum formula of plagioclase may be expressed as $\mathrm{MT}_{4} \mathrm{O}_{8}$ with the $\mathrm{M}$ site occupied by the large low-valence cations $\mathrm{Na}^{+}, \mathrm{Ca}^{2+}$ and $\mathrm{K}^{+}$and the $\mathrm{T}$ site occupied by the small high-valence cations $\mathrm{Si}^{4+}$ and $\mathrm{Al}^{3+}$. Ferric iron may substitute for $\mathrm{Al}^{3+}$ on the $\mathrm{T}$ site giving rise to the $\mathrm{CaFe}^{3+} \mathrm{AlSi}_{2} \mathrm{O}_{8}, \mathrm{NaFe}^{3+} \mathrm{Si}_{3} \mathrm{O}_{8}$, and $\mathrm{KFe}^{3+} \mathrm{Si}_{3} \mathrm{O}_{8}$ end-member components. Ferrous iron and magnesium may enter the $\mathrm{T}$ site, where they substitute for $\mathrm{Al}^{3+}$ implying the coupled substitution of $\mathrm{Al}^{3+}$ by $\mathrm{Si}^{4+}$, also on the $\mathrm{T}$ site. This gives rise to the $\mathrm{CaFe}^{2+} \mathrm{Si}_{3} \mathrm{O}_{8}$ and the $\mathrm{CaMgSi}_{3} \mathrm{O}_{8}$ end-member components. Alternatively, $\mathrm{Fe}^{2+}$ and $\mathrm{Mg}^{2+}$ may substitute for $\mathrm{Ca}^{2+}$ on the $\mathrm{M}$ site, which produces the $\mathrm{Fe}^{2+} \mathrm{Al}_{2} \mathrm{Si}_{2} \mathrm{O}_{8}$ and $\mathrm{MgAl}_{2} \mathrm{Si}_{2} \mathrm{O}_{8}$ end-member components. It was argued that $\mathrm{Fe}^{2+}$ and $\mathrm{Mg}^{2+}$ preferentially occupy the $\mathrm{T}$ site (Wenk and Wilde 1973; Longhi et al. 1976), but substitution of $\mathrm{Fe}^{2+}$ for $\mathrm{Ca}^{2+}$ on the $\mathrm{M}$ site has also been demonstrated by optical spectroscopy and electron paramagnetic resonance analysis (Bell and Mao 1973; Hofmeister and Rossman 1984). Experiments on basic magma revealed that the partitioning of $\mathrm{FeO}_{\mathrm{T}}$ into plagioclase is enhanced by high anorthite content of the plagioclase, by high oxygen fugacity, and by high silica content of the melt (Longhi et al. 1976; Phinney 1992). The enhancement of $\mathrm{Fe}$ incorporation with increasing anorthite content is ascribed to the increased availability of $\mathrm{Ca}^{2+}$ on the $\mathrm{M}$ site for substitution by $\mathrm{Fe}^{2+}$ and $\mathrm{Mg}^{2+}$ (Bell and Mao 1973; Hofmeister and Rossman 1984) and to the increased availability of $\mathrm{Al}^{3+}$ on the $\mathrm{T}$ site for substitution by $\mathrm{Fe}^{3+}$ (Lundgaard and Tegner 2004). The enhancement of $\mathrm{Fe}$ uptake with increasing $\mathrm{SiO}_{2}$ content of the melt has been ascribed to an increase of the activity of Fe-bearing species in the melt with increasing polymerization of the melt (Lundgaard and Tegner 2004). Finally, the enhancement of $\mathrm{Fe}$ uptake with increasing $f_{2}$ reflects the $\mathrm{Fe}^{3+} / \mathrm{FeO}_{\mathrm{T}}$ ratio in the melt coupled with the preferential substitution of $\mathrm{Fe}^{3+}$ for $\mathrm{Al}^{3+}$ on the T site (Lundgaard and Tegner 2004). Plagioclase from gabbroic rocks usually contains both ferric and ferrous iron, and the $\mathrm{Fe}^{3+} / \mathrm{FeO}_{\mathrm{T}}$ ratio is typically in the range of 0.4-0.7 (Nakada et al. 2019).

In a closed system setting, the Fe needed for precipitation of magnetite within the plagioclase host may thus well have been derived from the plagioclase host exclusively. The segregation of only $\mathrm{Fe}_{3} \mathrm{O}_{4}$ from plagioclase is, however, unlikely, as there is no phase component in plagioclase with this stoichiometry. Precipitation of magnetite from plagioclase in a closed system setting should be accompanied by the co-precipitation of additional phases. Composite inclusions containing orthopyroxene, clinopyroxene, amphibole or biotite in addition to magnetite are indeed observed. Out of these phases, amphibole and biotite appear to be related to late stage hydrothermal activity that postdates formation of the magnetite precipitates. This is why only mass balance scenarios for the precipitation of magnetite and of magnetite with accompanying pyroxene are discussed in the following paragraphs.

For analyzing chemical mass balance during the precipitation of magnetite and potentially accompanying pyroxene, we choose a set of 7 chemical components including $\mathrm{SiO}_{2}, \mathrm{Al}_{2} \mathrm{O}_{3}, \mathrm{FeO}, \mathrm{MgO}, \mathrm{CaO}, \mathrm{Na}_{2} \mathrm{O}$ and $\mathrm{O}_{2}$, and we allow for 13 phases or phase components including $\mathrm{CaAl}_{2} \mathrm{Si}_{2} \mathrm{O}_{8}$, $\mathrm{CaFe}^{3+} \mathrm{AlSi}_{2} \mathrm{O}_{8}, \mathrm{CaFe}^{2+} \mathrm{Si}_{3} \mathrm{O}_{8}, \mathrm{CaMgSi}_{3} \mathrm{O}_{8}, \mathrm{Fe}^{2+} \mathrm{Al}_{2} \mathrm{Si}_{2} \mathrm{O}_{8}$, $\mathrm{NaAlSi}_{3} \mathrm{O}_{8}, \mathrm{NaFe}^{3+} \mathrm{Si}_{3} \mathrm{O}_{8}, \mathrm{MgSiO}_{3}, \mathrm{FeSiO}_{3}, \mathrm{MgFe}^{3+}{ }_{2} \mathrm{O}_{4}$, $\mathrm{Fe}_{3} \mathrm{O}_{4}, \mathrm{CaSiO}_{3}$ and $\mathrm{O}_{2}$. For the chosen system, a stoichiometric reaction equation for the precipitation of magnetite and pyroxene from $\mathrm{Fe}$ - and/or $\mathrm{Mg}$-bearing plagioclase accompanied by a reduction of the $\mathrm{Fe}$ and/or $\mathrm{Mg}$ content of the plagioclase can be written (for details of the analysis see Appendix):

$$
\begin{aligned}
(2+ & 4 x) \mathrm{CaFe}^{3+} \mathrm{AlSi}_{2} \mathrm{O}_{8}+(4 x-1) \mathrm{Fe}^{2+} \mathrm{Al}_{2} \mathrm{Si}_{2} \mathrm{O}_{8} \\
& =1 \mathrm{Fe}_{3} \mathrm{O}_{4}+(2-2 x) \mathrm{CaFe}^{2+} \mathrm{Si}_{3} \mathrm{O}_{8}+6 x \mathrm{CaAl}_{2} \mathrm{Si}_{2} \mathrm{O}_{8} \\
& +(10 x-4) \mathrm{FeSiO}_{3}+x \mathrm{O}_{2}
\end{aligned}
$$


For $x>0.4$, both, magnetite and pyroxene are produced from $\mathrm{Fe}^{2+}$ - and $\mathrm{Fe}^{3+}$-bearing plagioclase, for $x=0.4$, only magnetite is formed. If $x<0.4$, pyroxene would be on the reactant side. In many cases, magnetite forms single-phase inclusions. In the composite inclusions, the accompanying pyroxene is volumetrically subordinate as compared to magnetite. Taking the oxygen equivalent as proxy for the proportions among the molar volume, the volumetric proportion of magnetite and pyroxene produced by the reaction according to Eq. 1 is $4: 3$, if $x=0.5$. This overrates the volume proportion of pyroxene as compared to what is observed in the composite inclusions, thus $0.4 \leq x \leq 0.5$ may be inferred, where $x$ is closer to 0.4 than to 0.5 .

For the given choice of phases and phase components, the formation of magnetite or of magnetite and pyroxene from Fe-bearing plagioclase liberates oxygen. Thus, such a reaction requires that the host plagioclase behaves as an open system with respect to oxygen but the cations can be balanced locally. From petrographic evidence, it may be inferred that the magnetite precipitates formed during or after development of the polysynthetic Albite twins. In addition, small precipitates of magnetite are concentrated along Albite twin boundaries, indicating that precipitation of magnetite was enhanced in the vicinity of the twin boundaries. The tendency of magnetite inclusions to form concentrations parallel to the Albite and Pericline twin planes was also reported from Whitney (1972) and by Sobolev (1990) corroborating links between the precipitation of magnetite and twinning in plagioclase. It may thus be hypothesized that the twin boundaries may have served as passageways for the exchange of oxygen between the interior of the plagioclase grain and the rock matrix.

We recall that the plagioclase grains are optically zoned with cloudy, inclusion-rich internal regions mantled by clear, inclusion-free regions at the rims, and, based on petrographic evidence, plagioclase is inferred to have been the first phase to crystallize from the melt. Mineral chemical analysis revealed that the early plagioclase growth zones incorporated $\mathrm{Fe}$ at $\mathrm{FeO}_{\mathrm{T}}$ levels of $0.5-1.0 \mathrm{wt} \%$ during primary magmatic crystallization from a tholeiitic melt. In a later stage, when pyroxene and Fe-Ti oxides started to crystallize, less Fe was available in the melt. This caused relatively low Fe contents in the late growth increments of the plagioclase, which now form the relatively Fe poor rims that are devoid of magnetite inclusions.

The precipitation of magnetite within the Fe-rich portions of the plagioclase was probably driven by a decrease of the $\mathrm{fO}_{2}$ in the rock matrix. The serpentinization of the associated ultramafic rocks, which may be represented by the simplified reaction:

$6 \mathrm{Mg}_{1.5} \mathrm{Fe}_{0.5} \mathrm{SiO}_{4}+7 \mathrm{H}_{2} \mathrm{O}=3 \mathrm{Mg}_{3}\left[\mathrm{Si}_{2} \mathrm{O}_{5}\right](\mathrm{OH})_{4}+\mathrm{Fe}_{3} \mathrm{O}_{4}+\mathrm{H}_{2}$, where $\mathrm{Mg}_{1.5} \mathrm{Fe}_{0.5} \mathrm{SiO}_{4}$ is olivine, and $\mathrm{Mg}_{3}\left[\mathrm{Si}_{2} \mathrm{O}_{5}\right](\mathrm{OH})_{4}$ is a simplified formula for a serpentine mineral, is an effective source for reducing fluids in a mid-ocean ridge environment (Klein et al. 2020). Thus, it is well conceivable that interaction of the gabbro with reducing fluids from serpentinization provided a driving force for the out-diffusion of oxygen from the plagioclase. This, in turn, leads to the partial reduction of the ferric iron originally contained in the plagioclase and precipitation of magnetite. According to Eq. 1, the precipitation of magnetite may, but need not necessarily be accompanied by the formation of orthopyroxene.

If chemical mass transfer into and out of the plagioclase host were possible not only for oxygen but also for the cations, any mass balance scenarios can be envisaged, and any association of inclusion phases, be it isolated magnetite, magnetite-orthopyroxene assemblages or more complex multiphase inclusions, could be formed by open system precipitation. The chemical mass transfer between the interior of the host plagioclase and the matrix cannot be explained by volume diffusion of trivalent cations through the lattice of plagioclase, because this process is exceedingly slow (Cherniak 2010). Fast diffusion pathways along one- or two-dimensional defects such as edge dislocations or twin boundaries would have to be invoked instead. If the magnetite inclusions indeed formed by introduction of $\mathrm{FeO}$ and $\mathrm{MgO}$ components from the rock matrix, the overall zoning of the plagioclase grains with the clouded, inclusion-rich core regions and the clear rims would require the rims to be of secondary nature. The regular optical zoning of the plagioclase grains, however, rather suggests a primary origin. Moreover, if Fe and $\mathrm{Mg}$ were supplied by their in-diffusion, also the rims of the plagioclase should have been affected. The rims are, however, less Fe rich than the core regions and free of magnetite micro-inclusions. Thus, precipitation of magnetite from Fe-bearing plagioclase that became supersaturated with respect to magnetite due to interaction with a reducing fluid from serpentinization of associated ultramafic rocks is considered the most likely formation pathway. The strong crystallographic orientation relationships between magnetite and orthopyroxene and the irregular shape of the magnetite-orthopyroxene interface suggests that during the reaction corresponding to Eq. 1, magnetite nucleated and grew first in contact with the plagioclase host, and orthopyroxene nucleated on the magnetite and partially replaced it somewhat later. The temperature at which this precipitation took place can be further constrained from the internal microstructures of the magnetite micro-inclusions. In this context, the ilmenite lamellae within the magnetite needles are of particular interest. 


\section{Implication of magnetite-ilmenite intergrowth}

As shown in Figs. 3 and 5, ilmenite is present in the magnetite inclusions in two microstructural variants. It may be present as single, relatively coarse, lath-shaped lamellae parallel to one of the MT\{111\} lattice planes of the magnetite host crystal. Typically, only a few of these coarse ilmenite lamellae are present within a single magnetite micro-inclusion, and they usually occupy less than 15 vol\% of the inclusions. The ilmenite shows a strong COR to the magnetite host with MT\{111\} \| ILM(0001) and MT $\{110\} \| \operatorname{ILM}(10 \overline{1}$ $0)$. In addition, small, several $\mathrm{nm}$-sized ilmenite grains are present dispersed in the hosting magnetite needle.

The microstructures and textures of magnetite-ilmenite intergrowth depend on the formation mechanisms (McConnell 1975; Speczik et al. 1988). At temperatures below $\sim 600^{\circ} \mathrm{C}$, Ti-rich magnetite tends to exsolve ulvospinel. Magnetite-ulvospinel assemblages obtained from exsolution of Ti-rich magnetite have been described from oceanic gabbro before (Feinberg et al. 2004; Ageeva et al. 2017), but are not typical in the sample under study. Ulvospinel is stable only at low oxygen fugacity and tends to be oxidized otherwise. The tendency for ulvospinel to become oxidized increases with decreasing temperature. This usually leads to low-temperature oxidation of ulvospinel that has exsolved from Ti-rich magnetite below $\sim 60{ }^{\circ} \mathrm{C}$, which characteristically produces fine ilmenite lamellae forming cloth microstructures, where the individual ilmenite lamellae are oriented parallel to the MT $\{100\}$ planes (Tan et al. 2016). This is not what is observed in the magnetite micro-inclusions under study. At higher $f \mathrm{O}_{2}$, the $\mathrm{Fe}_{2} \mathrm{TiO}_{4}$ component in Tirich magnetite usually becomes oxidized at temperatures above the magnetite-ulvospinel solvus by a reaction of the type

$6 \mathrm{Fe}_{2} \mathrm{TiO}_{4}+\mathrm{O}_{2}=6 \mathrm{FeTiO}_{3}+2 \mathrm{Fe}_{3} \mathrm{O}_{4}$.

This process is referred to as oxidation-exsolution and usually produces coarse, sandwich-like ilmenite lamellae in nearly pure magnetite. Ilmenite lamellae from oxidationexsolution are typically oriented parallel to the MT $\{111\}$ lattice planes with ILM(0001) \| MT\{111\}, which is compatible with our observations. Oxidation-exsolution is considered the most important pathway for the exsolution of ilmenite lamellae from Ti-rich magnetite (Tan et al. 2016). Oxidation-exsolution of ilmenite from Ti-rich magnetite occurs at temperatures above the crest of the magnetite-ulvospinel solvus, that is at temperatures in excess of $\sim 600{ }^{\circ} \mathrm{C}$. Cooling at constant oxygen fugacity shifts the equilibrium represented by Eq. 3 to the right side. As a consequence, cooling at constant $f \mathrm{O}_{2}$ is sufficient to drive exsolution of ilmenite or of an ilmenite-hematite solid-solution from Tirich magnetite.
At even higher temperatures, crystals of the magnetite-ulvospinel solid-solution series may incorporate appreciable amounts of $\mathrm{FeTiO}_{3}$ component, so that a non-stoichiometric, cation-deficient Ti-rich magnetite is produced. Such a non-stoichiometric, Ti-rich magnetite may be envisaged as a solid solution between an $\square \mathrm{Fe}^{2+}{ }_{4} \mathrm{Ti}^{4+}{ }_{4} \mathrm{O}_{12}$ and an $\mathrm{Fe}^{2+}{ }_{3} \mathrm{Fe}^{3+}{ }_{6} \mathrm{O}_{12}$ end-member component, where $\square$ denotes a cation vacancy (Lattard 1995; Lattard et al. 2005). It has been shown experimentally that cation-deficient Ti-rich magnetite becomes stoichiometric by exsolving ilmenite, when it is cooled below about $900{ }^{\circ} \mathrm{C}$ (Lattard 1995; Lattard et al. 2005; Tan et al. 2016), a process that is referred to as direct exsolution. Due to the limited incorporation of the $\mathrm{FeTiO}_{3}$ component into cation-deficient Ti-rich magnetite, the maximum amount of ilmenite that may be produced by direct exsolution is estimated to be less than about 15 vol\% (Taylor 1964).

The ilmenite lamellae observed in the magnetite microinclusions in the sample under study are compatible with both oxidation-exsolution and with direct exsolution from a non-stoichiometric Ti-rich magnetite. Both processes occur at temperatures above $\sim 600^{\circ} \mathrm{C}$. The generally small volume fraction of the ilmenite lamellae in the magnetite micro-inclusions may be taken as an indication for direct exsolution at $\geq 900{ }^{\circ} \mathrm{C}$. In any case, the observed magnetite-ilmenite intergrowth reflects processes that were operative at temperatures in excess of about $600{ }^{\circ} \mathrm{C}$ and testify to a high-temperature origin of the plagioclase-hosted magnetite micro-inclusions.

\section{Relation between magnetite formation and Albite twinning}

Most of the magnetite micro-inclusions are bounded by twin boundaries related to the polysynthetic Albite twins in the plagioclase host as shown in Fig. 1. Only inclusions with special CORs can actually pass through the twin boundaries. This phenomenon indicates that the inclusions most likely formed at the same time or after twinning had occurred. Albite twinning may occur during growth of plagioclase at low temperature, during cooling-induced monoclinic to triclinic symmetry change, or by deformation (Smith and Brown 1988). Growth twinning produced during low-temperature crystallization can be excluded for the magmatic plagioclases under study. Due to the lack of any associated deformation features, deformation twinning is regarded as unlikely. The morphology of the polysynthetic Albite twins and the frequently associated Pericline twins rather point to an origin as transformation twins. This view is corroborated by the presence of Carlsbad and Manebach twins, which are typically formed during the growth of monoclinic feldspar (Nespolo and Souvignier 2017). The presence of Carlsbad 
and Manebach twins indicates that the plagioclase originally grew with monoclinic symmetry and that the polysynthetic Albite twins formed as a result of cooling-induced highlow inversion (Seifert 1964). In albite, the transition from analbite to monalbite occurs at around $930{ }^{\circ} \mathrm{C}$ (Okamura and Ghose 1975). This puts an upper temperature limit on inclusion formation.

A schematic sketch illustrating the preferred genetic model for the formation of the oriented magnetite and composite micro-inclusions in plagioclase from oceanic gabbro is shown in Fig. 9. In the magmatic stage, the plagioclase crystallized from the melt forming growth twins after the Carlsbad and Manebach twin laws (Fig. 9a). In a second, supposedly late magmatic stage, polysynthetic twins after the Albite and Pericline twin laws were formed in plagioclase a process that was probably related to the monoclinic-triclinic transformation (Fig. 9b). Synchronously or after the Albite and Pericline twinning, Ti-rich magnetite started to precipitate from the plagioclase grain (Fig. 9c). Figure 9d shows a sketch of an individual titanomagnetite inclusion. The titanomagnetite inclusions may be accompanied by orthopyroxene and/or clinopyroxene (Fig. 9e).
Figure 9f shows the specific case described in Fig. 5a, where titanomagnetite exsolved lamellae ilmenite. In addition, mica formed during a late hydrothermal stage.

Plagioclase hosted, oriented needle-shaped magnetite micro-inclusions are a common phenomenon in igneous mafic rocks. Precipitation of the magnetite micro-inclusions from Fe-bearing plagioclase appears to be a viable formation pathway. Primary magmatic plagioclase from mafic igneous rocks has sufficiently high $\mathrm{FeO}_{\mathrm{T}}$ contents so that the $\mathrm{Fe}$ needed for the precipitation of magnetite can be derived from the plagioclase host exclusively. The mechanism by which an Fe-bearing plagioclase becomes supersaturated with respect to magnetite may differ between different environments. For the case at hand, interaction with a reducing fluid derived from the serpentinization of mantle peridotite is the most likely reason. Understanding the formation pathways and, in particular, constraining the crystallization temperature of the plagioclase-hosted magnetite micro-inclusion is highly relevant for paleomagnetic reconstructions. Moreover, the systematic SORs and CORs of the magnetite micro-inclusion with respect to the plagioclase host may potentially cause magnetic anisotropy,
Fig. 9 Schematic illustration of inclusion genesis. a Plagioclase with growth twinning after the Manebach or Carlsbad twin laws. b Plagioclase with polysynthetic twins due to twinning after the Albite twin law. c Oriented needle-shaped micro-inclusions of Timagnetite appear synchronous to or after Albite twinning. d Homogeneous Ti-magnetite micro-inclusions with prismatic shape and high aspect ratio in the plagioclase host. e Orthopyroxene grown on the magnetite simultaneously to or shortly after its precipitation from the plagioclase host. f Specific case with decomposition of Ti-magnetite into magnetite and ilmenite lamellae and mica that supposedly formed at a late hydrothermal stage as shown in Fig. 5 a

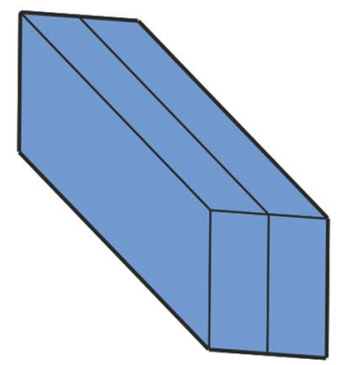

PL with growth twins

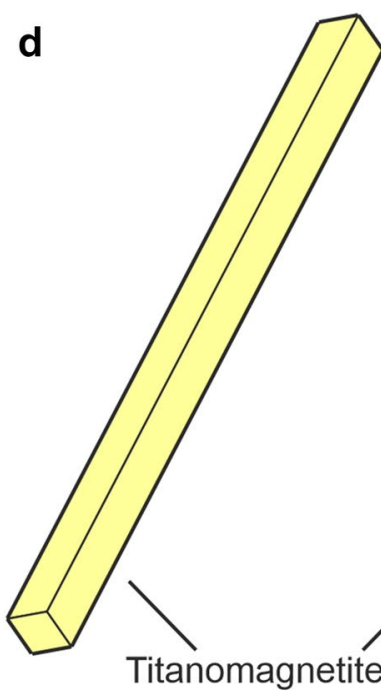

b

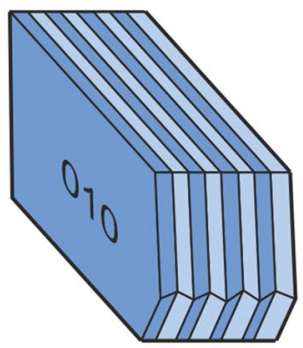

PL with polysynthetic transformation twins
C

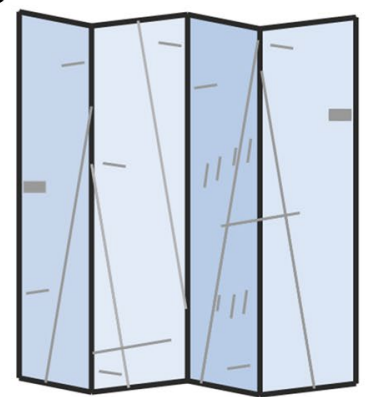

Ti-magnetite inclusions

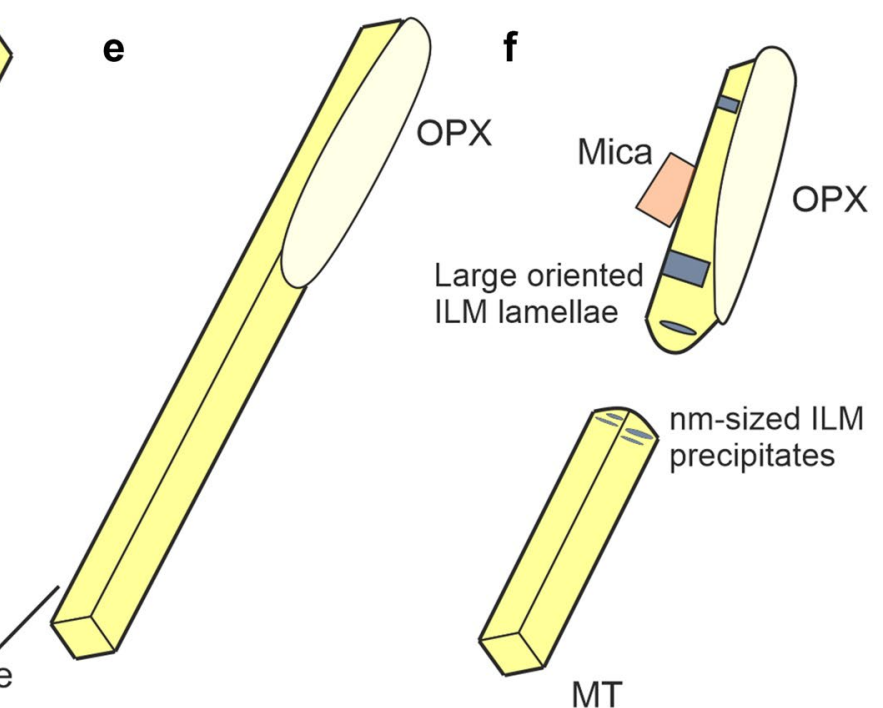


which is of particular importance in the context of single grain paleomagnetic techniques (Tarduno et al. 2006) and the analysis of rock magnetic fabric (Higgins 2006; Selkin et al. 2014). A systematic study trying to relate the statistical distribution of magnetite micro-inclusion orientations to the anisotropy of magnetic susceptibility and remanence is underway.

\section{Conclusions}

Oriented needle- and lath-shaped magnetite micro-inclusions in rock-forming plagioclase from oceanic gabbro dredged at the mid-Atlantic ridge at $13^{\circ} 01-02^{\prime} \mathrm{N}, 44^{\circ} 52^{\prime}$ $\mathrm{W}$ were investigated. The micro-inclusions show systematic shape and crystallographic orientation relationships with the plagioclase host. The magnetite needles are elongated along one of their MT $<111>$ directions and the needle elongation directions are aligned with one of the PL(112)n, PL(15 $0) n, \operatorname{PL}(\overline{3} 12) n, \operatorname{PL}(150) n$ or PL(100)n directions, where $\operatorname{PL}(h k l) n$ denotes the direction normal to the PL $(h k l)$ lattice plane. One additional inclusion type has its elongation direction parallel to one of the MT $<110>$ directions and the PL[001] direction. The orientation relationships are due to the good fit between oxygen layers in the crystal structures of both phases. The magnetite grains may be accompanied by subordinate ortho and/or clinopyroxene giving raise to composite inclusions. Both the single-phase magnetite as well as the composite magnetite-pyroxene micro-inclusions probably formed by exsolution from an Fe-bearing plagioclase. This process requires partial reduction of the ferric iron originally contained in the plagioclase and thus necessitates extraction of oxygen from the plagioclase. This probably occurred during interaction with reducing fluids from the serpentinization of associated ultramafic rocks, which drove out-diffusion of oxygen from the plagioclase grains.
The shape and crystallographic orientation relationships between the magnetite micro-inclusions and the plagioclase host follow the plagioclase lattice orientations in different plagioclase twin domains indicating that the inclusions were formed synchronous to or after twinning. The presence of up to about $15 \mathrm{vol} \%$ of oriented, relatively coarse ilmenite lamellae within the magnetite crystals indicates oxidationexsolution or direct exsolution from Ti-rich magnetite at temperatures $\geq 600{ }^{\circ} \mathrm{C}$. This is above the Curie temperature of magnetite implying that the magnetic signatures of the magnetite-bearing plagioclase grains represent thermoremanent magnetization.

\section{Appendix}

For analyzing possible mass balance scenarios for the precipitation of magnetite and potentially accompanying pyroxene from $\mathrm{Fe}$ - and $\mathrm{Mg}$-bearing plagioclase, we select a set of 7 components, including $\mathrm{SiO}_{2}, \mathrm{Al}_{2} \mathrm{O}_{3}, \mathrm{FeO}, \mathrm{MgO}, \mathrm{CaO}$, $\mathrm{Na}_{2} \mathrm{O}$, and $\mathrm{O}_{2}$, and we allow for 12 mineral phases or phase components $\mathrm{CaAl}_{2} \mathrm{Si}_{2} \mathrm{O}_{8}, \mathrm{CaFe}^{3+} \mathrm{AlSi}_{2} \mathrm{O}_{8}, \mathrm{CaFe}^{2+} \mathrm{Si}_{3} \mathrm{O}_{8}$, $\mathrm{CaMgSi}_{3} \mathrm{O}_{8}, \mathrm{Fe}^{2+} \mathrm{Al}_{2} \mathrm{Si}_{2} \mathrm{O}_{8}, \mathrm{NaAlSi}_{3} \mathrm{O}_{8}, \mathrm{NaFe}^{3+} \mathrm{Si}_{3} \mathrm{O}_{8}$, $\mathrm{MgSiO}_{3}, \mathrm{FeSiO}_{3}, \mathrm{MgFe}^{3+}{ }_{2} \mathrm{O}_{4}, \mathrm{Fe}_{3} \mathrm{O}_{4}, \mathrm{CaSiO}_{3}$ and oxygen. The sum formulae, abbreviations of the phase or phase component and the molar amounts of the oxide components contained in one formula unit of phase or phase component are given in Table 1. We define the composition vector of phase component $j$ as

$$
n_{j}=\left(\begin{array}{c}
n_{1}^{j} \\
n_{2}^{j} \\
\cdots \\
n_{c}^{j}
\end{array}\right) \text {, }
$$

Table 1 Sum formulae and molar contents of the chosen system components per mole of formula unit of the phases and phase components selected for describing mass balance scenarios for the precipitation of magnetite and potentially accompanying pyroxene from $\mathrm{Fe}-$ and $\mathrm{Mg}$-bearing plagioclase

\begin{tabular}{llllllll}
\hline Sum formula & $\mathrm{SiO}_{2}$ & $\mathrm{Al}_{2} \mathrm{O}_{3}$ & $\mathrm{FeO}$ & $\mathrm{MgO}$ & $\mathrm{CaO}$ & $\mathrm{Na}_{2} \mathrm{O}$ & $\mathrm{O}_{2}$ \\
\hline $\mathrm{CaAl}_{2} \mathrm{Si}_{2} \mathrm{O}_{8}$ & 2 & 1 & 0 & 0 & 1 & 0 & 0 \\
$\mathrm{CaFe}^{3+} \mathrm{AlSi}_{2} \mathrm{O}_{8}$ & 2 & 0.5 & 1 & 0 & 1 & 0 & 0.25 \\
$\mathrm{CaFe}^{2+} \mathrm{Si}_{3} \mathrm{O}_{8}$ & 3 & 0 & 1 & 0 & 1 & 0 & 0 \\
$\mathrm{CaMgSi}_{3} \mathrm{O}_{8}$ & 3 & 0 & 0 & 1 & 1 & 0 & 0 \\
$\mathrm{Fe}^{2+} \mathrm{Al}_{2} \mathrm{Si}_{2} \mathrm{O}_{8}$ & 2 & 1 & 1 & 0 & 0 & 0 & 0 \\
$\mathrm{NaAlSi}_{3} \mathrm{O}_{8}$ & 3 & 0.5 & 0 & 0 & 0 & 0.5 & 0 \\
$\mathrm{NaFe}^{3+} \mathrm{Si}_{3} \mathrm{O}_{8}$ & 3 & 0 & 1 & 0 & 0 & 0.5 & 0.25 \\
$\mathrm{FeSiO}_{3}$ & 1 & 0 & 1 & 0 & 0 & 0 & 0 \\
$\mathrm{MgSiO}_{3}$ & 1 & 0 & 0 & 1 & 0 & 0 & 0 \\
$\mathrm{CaSiO}_{3}$ & 1 & 0 & 0 & 0 & 1 & 0 & 0 \\
$\mathrm{Fe}_{3} \mathrm{O}_{4}$ & 0 & 0 & 3 & 0 & 0 & 0 & 0.5 \\
$\mathrm{MgFe}^{3+}{ }_{2} \mathrm{O}_{4}$ & 0 & 0 & 2 & 1 & 0 & 0 & 0.5 \\
$\mathrm{O}_{2}$ & 0 & 0 & 0 & 0 & 0 & 0 & 1 \\
\hline
\end{tabular}


where $n_{i}^{j}$ gives the number of moles of component $i$ contained per formula unit of phase or phase component $j$, and $c$ is the number of components. We now build a matrix $\mathbf{A}$ using the composition vectors of the twelve phases or phase components and of oxygen as the columns of $\mathbf{A}$ and calculate the orthonormal basis of the zero space of $\mathbf{A}$. This delivers a set of six linearly independent equations, which correspond to all linearly independent stoichiometric reaction equations that may be written among the phases and phase components:

$\mathrm{CaFe}^{3+} \mathrm{AlSi}_{2} \mathrm{O}_{8}+\mathrm{NaAlSi}_{3} \mathrm{O}_{8}=\mathrm{CaAl}_{2} \mathrm{Si}_{2} \mathrm{O}_{8}+\mathrm{NaFe}^{3+} \mathrm{Si}_{3} \mathrm{O}_{8}$

$\mathrm{CaMgSi}_{3} \mathrm{O}_{8}+\mathrm{FeSiO}_{3}=\mathrm{CaFe}^{2+} \mathrm{Si}_{3} \mathrm{O}_{8}+\mathrm{MgSiO}_{3}$

$\mathrm{CaAl}_{2} \mathrm{Si}_{2} \mathrm{O}_{8}+\mathrm{FeSiO}_{3}=\mathrm{Fe}^{2+} \mathrm{Al}_{2} \mathrm{Si}_{2} \mathrm{O}_{8}+\mathrm{CaSiO}_{3}$

$2 \mathrm{CaFe}^{3+} \mathrm{AlSi}_{2} \mathrm{O}_{8}+4 \mathrm{FeSiO}_{3}$

$$
=2 \mathrm{CaFe}^{2+} \mathrm{Si}_{3} \mathrm{O}_{8}+\mathrm{Fe}^{2+} \mathrm{Al}_{2} \mathrm{Si}_{2} \mathrm{O}_{8}+\mathrm{Fe}_{3} \mathrm{O}_{4}
$$

$$
\begin{aligned}
& 2 \mathrm{CaFe}^{3+} \mathrm{AlSi}_{2} \mathrm{O}_{8}+\mathrm{CaMgSi}_{3} \mathrm{O}_{8}+4 \mathrm{FeSiO}_{3} \\
& \quad=3 \mathrm{CaFe}^{2+} \mathrm{Si}_{3} \mathrm{O}_{8}+\mathrm{Fe}^{2+} \mathrm{Al}_{2} \mathrm{Si}_{2} \mathrm{O}_{8}+\mathrm{MgFe}_{2}^{3+} \mathrm{O}_{4}
\end{aligned}
$$

$$
\begin{aligned}
& 4 \mathrm{CaFe}^{3+} \mathrm{AlSi}_{2} \mathrm{O}_{8}+2 \mathrm{CaFe}^{2+} \mathrm{Si}_{3} \mathrm{O}_{8}+4 \mathrm{Fe}^{2+} \mathrm{Al}_{2} \mathrm{Si}_{2} \mathrm{O}_{8} \\
& =6 \mathrm{CaAl}_{2} \mathrm{Si}_{2} \mathrm{O}_{8}+10 \mathrm{FeSiO}_{3}+\mathrm{O}_{2}
\end{aligned}
$$

The stoichiometric equations of all possible reactions can be written as linear combinations of Eqs. 5-10. The first three equations correspond to cation exchange reactions. Equation 5 represents the exchange of $\mathrm{Al}$ and $\mathrm{Fe}^{3+}$ between $\mathrm{Ca}$ and $\mathrm{Na}$ plagioclase. Equation 6 represents the exchange of $\mathrm{Fe}^{2+}$ and $\mathrm{Mg}$ between Ca plagioclase and pyroxene. Equation 7 represents the exchange of $\mathrm{Fe}^{2+}$ and Ca between plagioclase and pyroxene. Equations 8-10 correspond to net-transfer reactions. Equation 8 represents a reaction producing magnetite from $\mathrm{Fe}^{3+}$-bearing plagioclase and $\mathrm{Fe}^{2+}$-bearing pyroxene. Equation 9 represents a reaction producing magnesioferrite from $\mathrm{Fe}$ - and $\mathrm{Mg}$-bearing Ca plagioclase and Fe pyroxene. Finally, Eq. 10 represents a reaction producing $\mathrm{Fe}$ pyroxene and oxygen from $\mathrm{Fe}$-bearing plagioclase.

From combining Eqs. 8 and 10, a reaction equation for the formation of magnetite or magnetite and pyroxene on the expense of $\mathrm{Fe}$-bearing $\mathrm{Ca}$ plagioclase is obtained. Taking Eq. $8+x$ Eq. 10, we have
For $0.4<x$, both magnetite and pyroxene are produced from Fe-bearing plagioclase; for $x=0.4$, only magnetite is formed. Equation 11 is written in the $\mathrm{Mg}$ - and $\mathrm{Na}$-free subsystem. Both components and the corresponding phase components may be involved by adding in Eqs. 5, 6, 7, and 9, so that $\mathrm{Mg}$ pyroxene, Ca pyroxene and magnesioferrite phase components would appear on the product side in addition.

Supplementary Information The online version contains supplementary material available at https://doi.org/10.1007/s00410-021-01864-8.

Acknowledgements The dredge samples were provided by courtesy of Alexey Pertsev. We gratefully acknowledge the constructive and helpful comments by three anonymous reviewers. Editorial hangling is gratefully acknowledged.

Author contributions All the authors contributed to the study conception and design. Material preparation, data collection, and analysis were performed by GB, OA, GH, AR and RA. The first draft of the manuscript was written by GB, and all the authors commented on previous versions of the manuscript. All the authors read and approved the final manuscript.

Funding Open access funding provided by University of Vienna. This research was funded by the Austrian Science Foundation (FWF) Grant Nr. I 3998-N29 and by the Russian Foundation for Basic Research (RFBR) Grant Nr. 18-55-14003. Support by Slovene Research Agency (ARRS) N1-0115 Grant is gratefully acknowledged.

\section{Declarations}

Conflict of interest The authors declare that they have no conflict of interest.

Ethical approval Hereby, the authors consciously assure that following statements are fulfilled: 1. this manuscript is the authors' original work, which has not been previously published elsewhere. 2 . This manuscript is not currently being reviewed for publications elsewhere. 3 . This manuscript reflects the authors' own research and analysis in a truthful and complete manner. 4 . This manuscript properly credits valuable contributions from co-authors. 5. All references are properly cited.

Consent to participate Hereby, the authors consciously assure that following statements are fulfilled: 1 . All the authors have contributions to the current manuscript. 2. All the authors take public responsibilities to the current manuscript.

Consent for publication Hereby, all the authors consent for the publication on Contributions to Mineralogy and Petrology.

Open Access This article is licensed under a Creative Commons Attribution 4.0 International License, which permits use, sharing, adaptation, distribution and reproduction in any medium or format, as long as you give appropriate credit to the original author(s) and the source, provide a link to the Creative Commons licence, and indicate if changes

$$
\begin{aligned}
& (2+4 x) \mathrm{CaFe}^{3+} \mathrm{AlSi}_{2} \mathrm{O}_{8}+(4 x-1) \mathrm{Fe}^{2+} \mathrm{Al}_{2} \mathrm{Si}_{2} \mathrm{O}_{8} \\
& \quad=1 \mathrm{Fe}_{3} \mathrm{O}_{4}+(2-2 x) \mathrm{CaFe}^{2+} \mathrm{Si}_{3} \mathrm{O}_{8}+6 x \mathrm{CaAl}_{2} \mathrm{Si}_{2} \mathrm{O}_{8}+(10 x-4) \mathrm{FeSiO}_{3}+x \mathrm{O}_{2}
\end{aligned}
$$


were made. The images or other third party material in this article are included in the article's Creative Commons licence, unless indicated otherwise in a credit line to the material. If material is not included in the article's Creative Commons licence and your intended use is not permitted by statutory regulation or exceeds the permitted use, you will need to obtain permission directly from the copyright holder. To view a copy of this licence, visit http://creativecommons.org/licenses/by/4.0/.

\section{References}

Ageeva O, Habler G, Topa D, Waitz T, Li C, Pertsev A, Griffiths T, Zhilicheva O, Abart R (2016) Plagioclase hosted Fe-Ti-oxide micro-inclusions in an oceanic gabbro-plagiogranite association from the Mid Atlantic ridge at 13 34' N. Am J Sci 316(2):85-109. https://doi.org/10.2475/02.2016.01

Ageeva O, Habler G, Pertsev A, Abart R (2017) Fe-Ti oxide microinclusions in clinopyroxene of oceanic gabbro: phase content, orientation relations and petrogenetic implication. Lithos 290291:104-115. https://doi.org/10.1016/j.lithos.2017.08.007

Ageeva O, Bian G, Habler G, Pertsev A, Abart R (2020) Crystallographic and shape orientations of magnetite micro-inclusions in plagioclase. Contrib Miner Petrol 175(10):1-16. https://doi.org/ 10.1007/s00410-020-01735-8

Ariskin AA, Barmina GS (2004) COMAGMAT: development of a magma crystallization model and its petrological applications. Geochem Int 42(1):S1

Bell P, Mao H (1973) Measurements of the polarized crystal field spectra of ferrous and ferric iron in seven terrestrial plagioclases. Carnegie Inst Wash Year Book 72:574-576

Bernstein S, Rosing MT, Brooks CK, Bird DK (1992) An ocean-ridge type magma chamber at a passive volcanic, continental margin: the Kap Edvard Holm layered gabbro complex, East Greenland. Geol Mag 129(4):437-456

Biedermann AR, Pettke T, Angel RJ, Hirt AM (2016) Anisotropy of magnetic susceptibility in alkali feldspar and plagioclase. Geophys Suppl Monthly Notices R Astron Soc 205(1):479-489

Biedermann AR, Jackson M, Chadima M, Hirt AM, Feinberg JM (2020) Beyond the second-order magnetic anisotropy tensor: higher-order components due to oriented magnetite exsolutions in pyroxenes, and implications for palaeomagnetic and structural interpretations. Geophys J Int 223(2):915-933. https://doi.org/10. 1093/gji/ggaa355

Brandriss ME, Bird DK (1999) Effects of H2O on phase relations during crystallization of gabbros in the Kap Edvard Holm Complex, East Greenland. J Petrol 40(6):1037-1064

Chang L, Roberts AP, Heslop D, Hayashida A, Li J, Zhao X, Tian W, Huang Q (2016) Widespread occurrence of silicate-hosted magnetic mineral inclusions in marine sediments and their contribution to paleomagnetic recording. J Geophys Res Solid Earth 121(12):8415-8431. https://doi.org/10.1002/2016JB013109

Cheadle MJ, Gee JS (2017) Quantitative textural insights into the formation of gabbro in mafic intrusions. Elements 13(6):409-414. https://doi.org/10.2138/gselements.13.6.409

Cherniak D (2010) Cation diffusion in feldspars. Rev Mineral Geochem 72(1):691-733

Davis KE (1981) Magnetite rods in plagioclase as the primary carrier of stable NRM in ocean floor gabbros. Earth Planet Sci Lett 55(1):190-198

Dunlop DJ (1981) The rock magnetism of fine particles. Phys Earth Planet Inter 26(1):1-26. https://doi.org/10.1016/0031-9201(81) 90093-5

Dunlop DJ, Özdemir Ö (2001) Rock magnetism: fundamentals and frontiers. Cambridge University Press
Feinberg JM, Wenk H-R, Renne PR, Scott GR (2004) Epitaxial relationships of clinopyroxene-hosted magnetite determined using electron backscatter diffraction (EBSD) technique. Am Miner 89(2-3):462-466

Feinberg JM, Scott GR, Renne PR, Wenk HR (2005) Exsolved magnetite inclusions in silicates: features determining their remanence behavior. Geology 33(6):513-516. https://doi.org/10. $1130 / \mathrm{g} 21290.1$

Feinberg JM, Harrison RJ, Kasama T, Dunin-Borkowski RE, Scott GR, Renne PR (2006) Effects of internal mineral structures on the magnetic remanence of silicate-hosted titanomagnetite inclusions: an electron holography study. J Geophys Res Solid Earth. https://doi.org/10.1029/2006jb004498

Fleet ME, Bilcox GA, Barnett RL (1980) Oriented magnetite inclusions in pyroxenes from the Grenville Province. Can Mineral 18(1):89-99

Gao W, Ciobanu CL, Cook NJ, Slattery A, Huang F, Wang D (2018) Nanoscale study of lamellar exsolutions in clinopyroxene from olivine gabbro: recording crystallization sequences in iron-rich layered intrusions. Am Mineral J Earth Planet Mater 104(2):244-264. https://doi.org/10.2138/am-2019-6764

Griffiths TA, Habler G, Abart R (2021) Determining the origin of inclusions in garnet: challenges and new diagnostic criteria. Am J Sci 320(9):753-789. https://doi.org/10.2475/11.2020.01

Grove TL, Baker MB (1984) Phase equilibrium controls on the tholeiitic versus calc-alkaline differentiation trends. J Geophys Res Solid Earth 89(B5):3253-3274

Grove TL, Kinzler RJ, Bryan WB (1992) Fractionation of mid-ocean ridge basalt (MORB). Mantle Flow Melt Gener mid-Ocean Ridges 71:281-310

Higgins MD (2006) Quantitative textural measurements in igneous and metamorphic petrology. Cambridge University Press

Hofmeister AM, Rossman GR (1984) Determination of Fe 3+ and $\mathrm{Fe} 2+$ concentrations in feldspar by optical absorption and EPR spectroscopy. Phys Chem Miner 11(5):213-224

Kent DV, Honnorez BM, Opdyke ND, Fox PJ (1978) Magnetic properties of dredged oceanic gabbros and the source of marine magnetic anomalies. Geophys J Int 55(3):513-537. https://doi. org/10.1111/j.1365-246X.1978.tb05925.x

Klein F, Tarnas JD, Bach W (2020) Abiotic sources of molecular hydrogen on earth. Elements 16(1):19-24. https://doi.org/10. 2138/gselements.16.1.19

Knafelc J, Filiberto J, Ferré EC, Conder JA, Costello L, Crandall JR, Dyar MD, Friedman SA, Hummer DR, Schwenzer SP (2019) The effect of oxidation on the mineralogy and magnetic properties of olivine. Am Miner J Earth Planet Mater 104(5):694-702

Lappe SCL, Church NS, Kasama T, da Silva Fanta AB, Bromiley G, Dunin-Borkowski RE, Feinberg JM, Russell S, Harrison RJ (2011) Mineral magnetism of dusty olivine: a credible recorder of pre-accretionary remanence. Geochem Geophys Geosyst. https://doi.org/10.1029/2011GC003811

Lattard D (1995) Experimental evidence for the exsolution of ilmenite from titaniferous spinel. Am Miner 80(9-10):968-981

Lattard D, Sauerzapf U, Käsemann M (2005) New calibration data for the $\mathrm{Fe}$-Ti oxide thermo-oxybarometers from experiments in the $\mathrm{Fe}-\mathrm{Ti}-\mathrm{O}$ system at $1 \mathrm{bar}, 1000-1300 \mathrm{C}$ and a large range of oxygen fugacities. Contrib Miner Petrol 149(6):735-754

Longhi J, Walker D, Hays JF (1976) Fe and Mg in plagioclase. In: Lunar and planetary science conference proceedings, vol 7.pp $1281-1300$

Lundgaard KL, Tegner C (2004) Partitioning of ferric and ferrous iron between plagioclase and silicate melt. Contrib Miner Petrol 147(4):470-483. https://doi.org/10.1007/s00410-004-0568-0

McConnell J (1975) Microstructures of minerals as petrogenetic indicators. Annu Rev Earth Planet Sci 3(1):129-155 
Nakada R, Sato M, Ushioda M, Tamura Y, Yamamoto S (2019) Variation of iron species in plagioclase crystals by X-ray absorption fine structure analysis. Geochem Geophys Geosyst 20(11):5319-5333. https://doi.org/10.1029/2018gc008131

Nespolo M, Souvignier B (2017) Structural analysis of twins in feldspars. I. Carlsbad twinning. Eur J Mineral 29(6):939-947. https:// doi.org/10.1127/ejm/2017/0029-2678

Nikolaisen ES, Harrison RJ, Fabian K, McEnroe SA (2020) Hysteresis of natural magnetite ensembles: micromagnetics of silicate-hosted magnetite inclusions based on focused-ion-beam nanotomography. Geochem Geophys Geosyst. https://doi.org/10.1029/2020g c009389

Okamura FP, Ghose S (1975) Analbite $\rightarrow$ monalbite transition in a heat treated twinned amelia albite. Contrib Miner Petrol 50(3):211-216

Ondréas H, Cannat M, Fouquet Y, Normand A (2012) Geological context and vents morphology of the ultramafic-hosted Ashadze hydrothermal areas (Mid-Atlantic Ridge $13^{\circ} \mathrm{N}$ ). Geochem Geophys Geosyst. https://doi.org/10.1029/2012GC004433

O'Neill HSC, Dollase W (1994) Crystal structures and cation distributions in simple spinels from powder XRD structural refinements: $\mathrm{MgCr} 2 \mathrm{O}$ 4, $\mathrm{ZnCr} 2 \mathrm{O}$ 4, Fe $3 \mathrm{O} 4$ and the temperature dependence of the cation distribution in $\mathrm{ZnAl} 2 \mathrm{O}$ 4. Phys Chem Miner 20(8):541-555

Peirce C, Reveley G, Robinson AH, Funnell MJ, Searle RC, Simão NM, MacLeod CJ, Reston TJ (2019) Constraints on crustal structure of adjacent OCCs and segment boundaries at $13^{\circ} \mathrm{N}$ on the Mid-Atlantic Ridge. Geophys J Int 217(2):988-1010. https://doi. org/10.1093/gji/ggz074

Peirce C, Robinson AH, Funnell MJ, Searle RC, MacLeod CJ, Reston TJ (2020) Magmatism versus serpentinization-crustal structure along the $13^{\circ} \mathrm{N}$ segment at the Mid-Atlantic Ridge. Geophys J Int 221(2):981-1001. https://doi.org/10.1093/gji/ggaa052

Phinney W (1992) Partition coefficients for iron between plagioclase and basalt as a function of oxygen fugacity: Implications for Archean and lunar anorthosites. Geochim Cosmochim Acta 56(5):1885-1895

Proyer A, Habler G, Abart R, Wirth R, Krenn K, Hoinkes G (2013) $\mathrm{TiO} 2$ exsolution from garnet by open-system precipitation: Evidence from crystallographic and shape preferred orientation of rutile inclusions. Contrib Miner Petrol 166(1):211-234

Renne PR, Scott GR, Glen JMG, Feinberg JM (2002) Oriented inclusions of magnetite in clinopyroxene: source of stable remanent magnetization in gabbros of the Messum Complex, Namibia. Geochem Geophys Geosyst 3(12):1-11. https://doi.org/10.1029/ $2002 \mathrm{gc} 000319$

Seifert KE (1964) The genesis of plagioclase twinning in the Nonewaug granite. Am Mineral 49:297-320

Selkin PA, Gee JS, Meurer WP (2014) Magnetic anisotropy as a tracer of crystal accumulation and transport, Middle Banded Series, Stillwater Complex, Montana. Tectonophysics 629:123-137. https://doi.org/10.1016/j.tecto.2014.03.028

Silantyev SA, Krasnova EA, Cannat M, Bortnikov NS, Kononkova NN, Beltenev VE (2011) Peridotite-gabbro-trondhjemite association of the Mid-Atlantic Ridge between $12^{\circ} 58^{\prime}$ and $14^{\circ} 45^{\prime} \mathrm{N}$ : Ashadze and Logachev hydrothermal vent fields. Geochem Int 49(4):323-354. https://doi.org/10.1134/S0016702911040070

Smith JV, Brown WL (1988) Felspar minerals. Springer-Verlag, Berlin Heidelberg

Smith DK, Escartín J, Schouten H, Cann JR (2008) Fault rotation and core complex formation: Significant processes in seafloor formation at slow-spreading mid-ocean ridges (Mid-Atlantic Ridge, $\left.13^{\circ}-15^{\circ} \mathrm{N}\right)$. Geochem Geophys Geosyst. https://doi.org/10.1029/ 2007GC001699

Sobolev PO (1990) Orientation of acicular iron-ore mineral inclusions in plagioclase. Int Geol Rev 32(6):616-628. https://doi.org/10. 1080/00206819009465804

Speczik S, Wiszniewska J, Diedel R (1988) Minerals, exsolution features and geochemistry of Fe-Ti ores of the Suwałki district (North-East Poland). Miner Deposita 23(3):200-210

Suhr G, Hellebrand E, Johnson K, Brunelli D (2008) Stacked gabbro units and intervening mantle: a detailed look at a section of IODP Leg 305, Hole U1309D. Geochem Geophys Geosyst. https://doi. org/10.1029/2008GC002012

Tan W, Liu P, He H, Wang CY, Liang X (2016) Mineralogy and origin of exsolution in Ti-rich magnetite from different magmatic Fe-Ti oxide-bearing intrusions. Can Mineral 54(3):539-553. https://doi. org/10.3749/canmin.1400069

Tarduno JA, Cottrell RD, Smirnov AV (2006) The paleomagnetism of single silicate crystals: recording geomagnetic field strength during mixed polarity intervals, superchrons, and inner core growth. Rev Geophys. https://doi.org/10.1029/2005rg000189

Tarduno JA, Cottrell RD, Bono RK, Oda H, Davis WJ, Fayek M, Ovt E, Nimmo F, Huang W, Thern ER, Fearn S, Mitra G, Smirnov AV, Blackman EG (2020) Paleomagnetism indicates that primary magnetite in zircon records a strong Hadean geodynamo. Proc Natl Acad Sci 117(5):2309-2318. https://doi.org/10.1073/pnas. 1916553117

Taylor RW (1964) Phase equilibria in the system FeO-Fe2O3-TiO2 AT $1300^{\circ}$ C. Am Mineral J Earth Planet Mater 49(7-8):1016-1030

Tegner C (1997) Iron in plagioclase as a monitor of the differentiation of the Skaergaard intrusion. Contrib Miner Petrol 128(1):45-51

Usui Y, Shibuya T, Sawaki Y, Komiya T (2015) Rock magnetism of tiny exsolved magnetite in plagioclase from a Paleoarchean granitoid in the Pilbara craton. Geochem Geophys Geosyst 16(1):112-125

Vance JA (1969) On synneusis. Contrib Miner Petrol 24(1):7-29. https://doi.org/10.1007/BF00398750

Villiger S, Ulmer P, Müntener O (2007) Equilibrium and fractional crystallization experiments at $0.7 \mathrm{GPa}$; the effect of pressure on phase relations and liquid compositions of tholeiitic magmas. $\mathbf{J}$ Petrol 48(1):159-184

Wager LR, Mitchell RL (1951) The distribution of trace elements during strong fractionation of basic magma - a further study of the Skaergaard intrusion, East Greenland. Geochim Cosmochim Acta 1(3):129-208. https://doi.org/10.1016/0016-7037(51)90016-6

Wenk H-R, Wilde W (1973) Chemical anomalies of lunar plagioclase, described by substitution vectors and their relation to optical and structural properties. Contrib Miner Petrol 41(2):89-104

Wenk HR, Joswig W, Tagai T, Korekawa M, Smith BK (1980) The average structure of An 62-66 labradorite. Am Miner 65(1-2):81-95

Wenk HR, Chen K, Smith R (2011) Morphology and microstructure of magnetite and ilmenite inclusions in plagioclase from Adirondack anorthositic gneiss. Am Miner 96(8-9):1316-1324. https://doi. org/10.2138/am.2011.3760

Whitney PR (1972) Spinel inclusions in plagioclase of metagabbros from the Adirondack Highlands. Ame Mineral J Earth Planet Mater 57(9-10):1429-1436

Publisher's Note Springer Nature remains neutral with regard to jurisdictional claims in published maps and institutional affiliations. 